\title{
A PRELIMINARY OVERVIEW OF SKIN AND SKELETAL DISEASES AND TRAUMATA IN SMALl CETACEANS FROM SOUTH AMERICAN WATERS
}

\author{
Marie-Françoise Van Bressem ${ }^{1, *}$, Koen Van Waerebeek ${ }^{1}$, Julio C. Reyes'², Fernando Félix ${ }^{3}$, Mónica Echegaray², \\ Salvatore Siciliano ${ }^{4}$, Ana Paula Di Beneditto ${ }^{5}$, Leonardo Flach ${ }^{6}$, Francisco Viddi ${ }^{7}$, Isabel Cristina Avila ${ }^{8}$, \\ Julio César Herrera ${ }^{9}$, Isabel Cristina Tobón ${ }^{9}$, Jaime Bolaños-Jiménez ${ }^{10}$, Ignacio B. Moreno ${ }^{11}$, Paulo H. OtT ${ }^{11,12}$, \\ Gian Paolo Sanino ${ }^{13}$, Elena Castineira ${ }^{14}$, David Montes ${ }^{1}$, Enrique Crespo ${ }^{15}$, Paulo A.C. Flores ${ }^{16}$, Ben HaAse ${ }^{3}$, \\ Sheila M. F. Mendonça de Souza ${ }^{4}$, Maíra Laeta ${ }^{4}$ and Ana Bernadete Fragoso ${ }^{17}$
}

\begin{abstract}
Aвstract: We succinctly review and document new cases of diseases of the skin and the skeletal system and external traumata in cetaceans from Ecuador, Colombia, Peru, Chile, Argentina, Uruguay, Brazil, and Venezuela. The survey revealed 590 cases diagnosed with a significant pathology, injury or malformation on a total of 7635 specimens of 12 odontocete species examined or observed in 1984-2007. Tattoo skin disease (TSD), lobomycosis-like disease (LLD) and cutaneous diseases of unknown aetiology seem to be emerging in several populations. TSD was confirmed in eight species from the SE Pacific and SW Atlantic. LLD affected only inshore Tursiops truncatus but was found in four tropical countries, namely Colombia, Ecuador, Peru and Brazil. Lobomycosis was confirmed by histology in one male from the Tramandaí estuary, southern Brazil. All LLD-affected specimens were encountered in the vicinity of major ports and cities and a possible association with chemical or organic water pollution is suspected. Whitish velvety cutaneous marks associated with scars occurred in inshore T. truncatus, Sotalia guianensis and Pseudorca crassidens. Large, rounded lesions were seen in a Cephalorhynchus eutropia calf and a C. commersonii. Cutaneous wounds and scars as well as body traumata possibly related to net entanglements and boat collisions were observed in 73 delphinids and Phocoena spinipinnis. Traumatic injuries resulted in the partial or complete amputation and other disfiguring scars of appendages in 17 cases. Fractures of the skull, ribs and vertebrae thought to be caused by fisheries-related interactions or boat collisions were seen in single individuals of Delphinus capensis, Lagenorhynchus obscurus, T. truncatus, S. guianensis and Ziphius cavirostris. Prevalence of osteopathology in small cetaceans from Peru, Brazil and Venezuela ranged widely, from 5.4\% to 69.1\%. In four species from Peru, lytic cranial lesions were the most frequently observed disease (5.4\%-42.9\%), followed by hyperostosis and ankylosing spondylitis in offshore $(31 \%, \mathrm{n}=42)$ and inshore $(15.4 \%, \mathrm{n}=26) \mathrm{T}$. truncatus. Fractures and other bone traumata were present in $47.2 \%$ of 53 axial skeletons of S. guianensis from the northern Rio de Janeiro state (Brazil) in 19871998. A high prevalence $(48.4 \%, \mathrm{n}=31)$ of, apparently congenital, malformations of cervical vertebrae, observed in a $2001-2006$ sample, may be explained by a hypothetical genetic bottleneck in this population. Malformations with deficient ossification would clearly increase susceptibility for fractures. This study demonstrates the utility of a continent-wide analysis to discern epizootiological trends more readily than any local study could provide. Secondly, it underscores the need for focussed research on the effects of human activities on the spread of diseases in cetaceans, particularly in near-shore populations that utilize highly degraded coastal habitats.
\end{abstract}

RESUmen: En este trabajo revisamos y documentamos brevemente nuevos casos de enfermedades de piel y de esqueleto, y traumas externos en cetáceos de Ecuador, Colombia, Perú, Chile, Argentina, Uruguay, Brasil y Venezuela. De un total de 7635 especímenes de 12 especies de odontocetos examinados entre 1984 y 2007, se encontraron 590 casos con una patología significativa, heridas o malformaciónes. Las condiciones conocidas como 'enfermedad cutánea de tatuaje' (TSD), 'enfermedad

${ }^{1}$ Cetacean Conservation Medicine Group (CMED-CEPEC), Museo de Delfines, Pucusana, Peru.

* Corresponding author, e-mails: marievanbressem@yahoo.co.uk and mfb.cmed@gmail.com.

2 Áreas Costeras y Recursos Marinos (ACOREMA). Av. San Martín 1471, Pisco, Peru.

${ }^{3}$ Fundación Ecuatoriana para el Estudio de Mamíferos Marinos (FEMM). PO Box 09-01-11905, Guayaquil, Ecuador.

${ }^{4}$ Grupo de Estudos de Mamíferos Marinhos da Região dos Lagos (GEMM-Lagos) \& Laboratório de Ecologia, Departamento de Endemias Samuel Pessoa, Escola Nacional de Saúde Pública/FIOCRUZ. Rua Leopoldo Bulhões, 1480-térreo, Manguinhos, Rio de Janeiro, RJ 21041-210 Brazil.

${ }^{5}$ Universidade Estadual do Norte Fluminense-CBB, Laboratório de Ciências Ambientais. Av. A. Lamego, 2000, Campos dos Goytacazes, RJ 28013-602 Brazil.

${ }^{6}$ Projeto Boto Cinza - MBR - Um Grupo CAEMI. Rua Sta Terezinha, 531 - 90 Vila Muriqui, Mangaratiba, RJ 23860-000 Brazil.

${ }^{7}$ Marine Mammal Research Group, Graduate School of the Environment, Macquarie University, NSW 2109 Sydney, Australia and Centro Ballena Azul, Valdivia, Chile.

${ }^{8}$ Universidad del Valle, Departamento de Biología, Grupo de Investigación en Ecología Animal, Cali, Colombia.

${ }^{9}$ Fundación Yubarta. Carrera 24 F Oeste No. 3-110, Tejares De San Fernando, Cali (Valle), Colombia.

${ }^{10}$ Sociedad Ecológica Venezolana Vida Marina (Sea Vida). A.P. 162, Cagua, Estado Aragua, Venezuela 2122.

${ }^{11}$ Grupo de Estudos de Mamíferos Aquáticos do Rio Grande do Sul (GEMARS) \& Centro de Estudos Costeiros, Limnológicos e Marinhos da Universidade Federal do Rio Grande do Sul (CECLIMAR/UFRGS). Rua Felipe Néri, 382/203, Porto Alegre, RS 90440-150 Brazil.

${ }^{12}$ Universidade Estadual do Rio Grande do Sul (UERGS). Cidreira, RS, Brazil.

${ }^{13}$ Centre for Marine Mammals Research LEVIATHAN. 7640392 Chile.

${ }^{14}$ Facultad de Ciencias, Universidad de la República. Montevideo, Uruguay.

${ }^{15}$ Centro Nacional Patagónico (CONICET). Boulevard Brown 3600, 9120 Puerto Madryn, Chubut, Argentina.

${ }^{16}$ Centro Mamíferos Aquáticos (CMA) \& Núcleo de Unidades de Conservação (NUC), Instituto CM de Conservação da Biodiversidade (Icmbio) \& Ibama. R. Min. João G. de Souza, s/n, Dist. Industrial, Manaus, AM 69075-830 Brazil, and Instituto de Pesquisa e Conservação de Golfinhos, Florianópolis, SC Brazil.

${ }^{17}$ Projeto Maqua - UERJ, Maracanã, Rio de Janeiro, RJ 20000-000 Brazil. 
parecida a lobomicosis' (LLD) y enfermedades cutáneas de etiología desconocida parecen estar emergiendo en varias poblaciones de cetáceos. La presencia de TSD fue confirmada en ocho especies del Pacífico Sureste y del Atlántico Suroeste. LLD se encontró solamente en Tursiops truncatus costeros en cuatro países tropicales: Colombia, Ecuador, Perú y Brasil. Un caso de lobomicosis fue confirmado por histología en un macho de T. truncatus del estuario de Tramandaí en el sur de Brasil. Todos los especímenes con LLD fueron encontrados en la proximidad de puertos grandes y ciudades, y se sospecha una asociación con la contaminación química u orgánica del agua. En T. truncatus costeros, Sotalia guianensis y Pseudorca crassidens se observaron lesiones cutáneas blanquecinas y aterciopeladas asociadas con cicatrices. Grandes lesiones redondas fueron vistas en una cría de Cephalorhynchus eutropia y en un ejemplar de C. commersonii. Heridas cutáneas y cicatrices, así como traumas corporales, posiblemente relacionados con la captura en redes de pesca y colisiones con botes fueron registradas en 73 delfines y en Phocoena spinipinnis. Algunos traumas provocaron desde cicatrices desfigurantes hasta la amputación total o parcial de las aletas o de la cola de 17 espécimenes. Fracturas del cráneo, de las costillas y de las vertebras, posiblemente causadas por interacciones violentas con pesquerías o colisiones con botes fueron observadas en individuos de Delphinus capensis, Lagenorhynchus obscurus, T. truncatus, S. guianensis y Ziphius cavirostris. La prevalencia de patologías óseas en pequeños cetáceos de Brasil, Perú y Venezuela osciló ampliamente entre 5.4\% y 69.1\% del total de los animales analizados. Las lesiones líticas del cráneo en L. obscurus, D. capensis, T. truncatus y P. spinipinnis del Perú constituyeron las enfermedades más frecuentemente observadas $(5.4 \%-42.9 \%)$, seguidas por hiperostosis y espondilitis anquilosante en $T$. truncatus oceánicos $(31 \%, \mathrm{n}=42)$ y costeros $(15.4 \%, \mathrm{n}=26)$. Fracturas y otros traumas óseos fueron registrados en el $47.2 \%$ de 53 esqueletos de $S$. guianensis en el norte del estado de Rio de Janeiro (Brasil) entre 1987 y 1998. La alta prevalencia de malformaciones, probablemente congénitas de las vertebras cervicales en una muestra colectada entre los años 2001 y 2006, puede ser debida a una situación de cuello de botella genético en esta población. Las malformaciones con déficit de osificación aumentarían claramente la predisposición a las fracturas. Este estudio demuestra la importancia de un análisis a escala regional, ya que en éste se disciernen las tendencias epizootiológicas más fácilmente que en investigaciones a nivel local. Además indica la necesidad de una investigación dedicada a estudiar los efectos que tienen las actividades humanas en la diseminación de las enfermedades en cetáceos, especialmente en las poblaciones costeras que viven en un ambiente altamente deteriorado.

KEYwORDs: Cetaceans, diseases, skin, skeleton, traumata, malformations, epidemiology, South America, pollution.

\section{Introduction}

More than half $(57.7 \%)$ of the 71 recognized odontocete species of the world inhabit the extensive marine and freshwaters of South America. There, as in many other areas, they face a host of human-caused threats including incidental mortality in fisheries, direct exploitation, vessel strikes as well as habitat degradation and loss, and a significant number of populations are considered vulnerable. Especially for the latter, any source of enhanced natural or anthropogenic mortality or morbidity should be of concern.

Although dedicated research on the epizootiology of infectious diseases is still in an early phase in South American (SA) cetaceans, a number of viruses, bacteria and disease-causing macroparasites have been documented in several species (see Table 1). Some have the potential for significant adverse impacts on population abundance by increasing baseline natural mortality (e.g. cetacean morbilliviruses, Crassicauda spp. nematodes and, possibly, cetacean poxviruses) or by negatively affecting reproduction (e.g. Brucella spp., Phocoena spinipinnis papillomavirus type 1) (Van Bressem and Van Waerebeek, 1996; Van Bressem et al., 1996; 1998; 1999; 2001a,b; 2006a; 2007a,b). Brucella spp. and cetacean poxviruses possibly represent a zoonotic threat (Van Bressem et al., 1993; 2001a; 2007b). Miscellaneous non-infectious diseases, lesions, anomalies and traumata are also commonly found in SA small cetaceans (e.g. Van Bressem et al., 2000; 2006b; Ramos et al., 2001; Sánchez et al., 2002; Flores et al., 2005 ${ }^{18}$; Flach, 2006 ${ }^{19}$; Laeta et al., 2006 ${ }^{20}$; Mendonça de Souza et al., 2006 ${ }^{21}$ ) and may also have a negative impact on reproductive success, impair feeding or cause premature death (Van Bressem et al., 2000; 2006b; Ramos et al., 2001; Sánchez et al., 2002; Siciliano et al., in press). Anthropogenic activities may influence the course of diseases as well as directly cause traumata and lesions (Van Bressem et al., 1994; 1999; 2001b; Ross, 2002; Viddi et al., 200522; Flach, 2006 ${ }^{19}$ ).

${ }^{18}$ Flores, P.A.C., Bazzalo, M., Da Silva, L.Z. and Wells, R.S. (2005) Evidência de residência individual e ocorrência de lesões epidérmicas em golfinhos Tursiops truncatus na Baía Norte, SC, Brasil Page 87 in: Abstracts, III Congresso Brasileiro de Mastozoologia, 12-16 October, 2005, Aracruz, ES, Brazil.

${ }^{19}$ Flach, L. (2006) Photo-identification study reveals human threats towards estuarine dolphins in southeast Brazil. Page 46 in: Siciliano, S., Borobia, M., Barros, N.B., Marques, F.C., Trujillo, T. and Flores, P.A.C. (Eds) Workshop on Research and Conservation of the Genus Sotalia, 19-23 June 2006, Armação dos Búzios, RJ, Brazil.

${ }^{20}$ Laeta, M., Mendonça de Souza, S.M.F. and Siciliano, S. (2006) Anomalias congênitas em Sotalia guianensis da costa norte da estado do Rio de Janeiro- Brasil. Page 123 in Abstracts, I Congresso Sul-Americano de Mastozoologia, 5-8 October 2006, Gramado, RS, Brazil.

${ }^{21}$ Mendonça de Souza, S.M.F., Laeta, M., and Siciliano, S. (2006) Lesões ósseas em colunas vertebrais de golfinhos do gênero Sotalia, provenientes do litoral norte do Rio de Janeiro, Brasil. Page 32 in Siciliano, S., Borobia, M., Barros, N.B., Marques, F.C., Trujillo, F., Flores, P.A.C. (Eds) Workshop on Research and Conservation of the Genus Sotalia, 19-23 June 2006.Armação dos Búzios, RJ, Brazil,

${ }^{22}$ Viddi, F.A., Van Bressem, M.-F., Bello, M. and Lescrauwaet, A.K. (2005) First records of skin lesions in coastal dolphins off southern Chile. 16th Biennial Conference on the Biology of Marine Mammals, 12-16 December 2005, San Diego, CA, USA. 


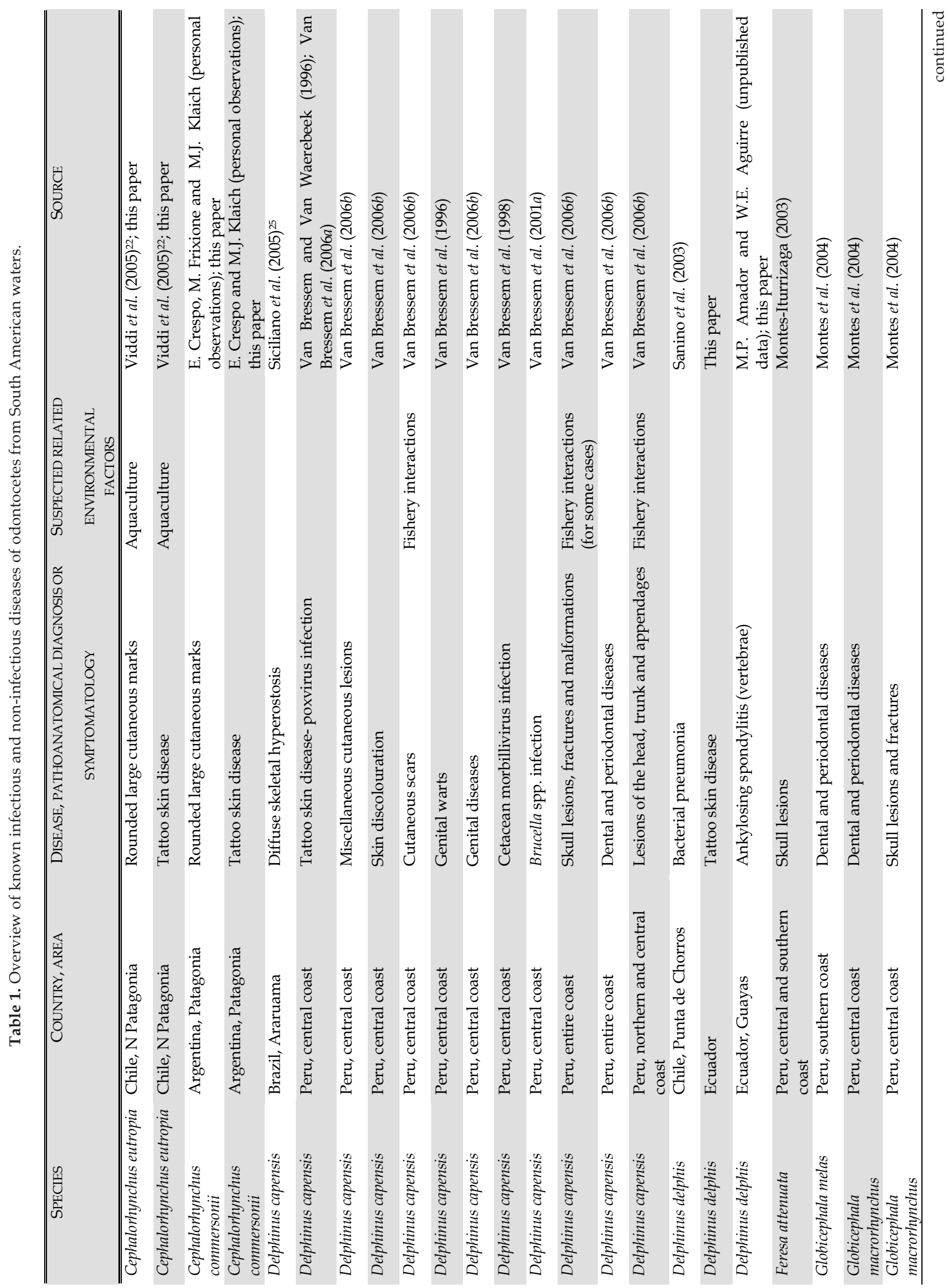




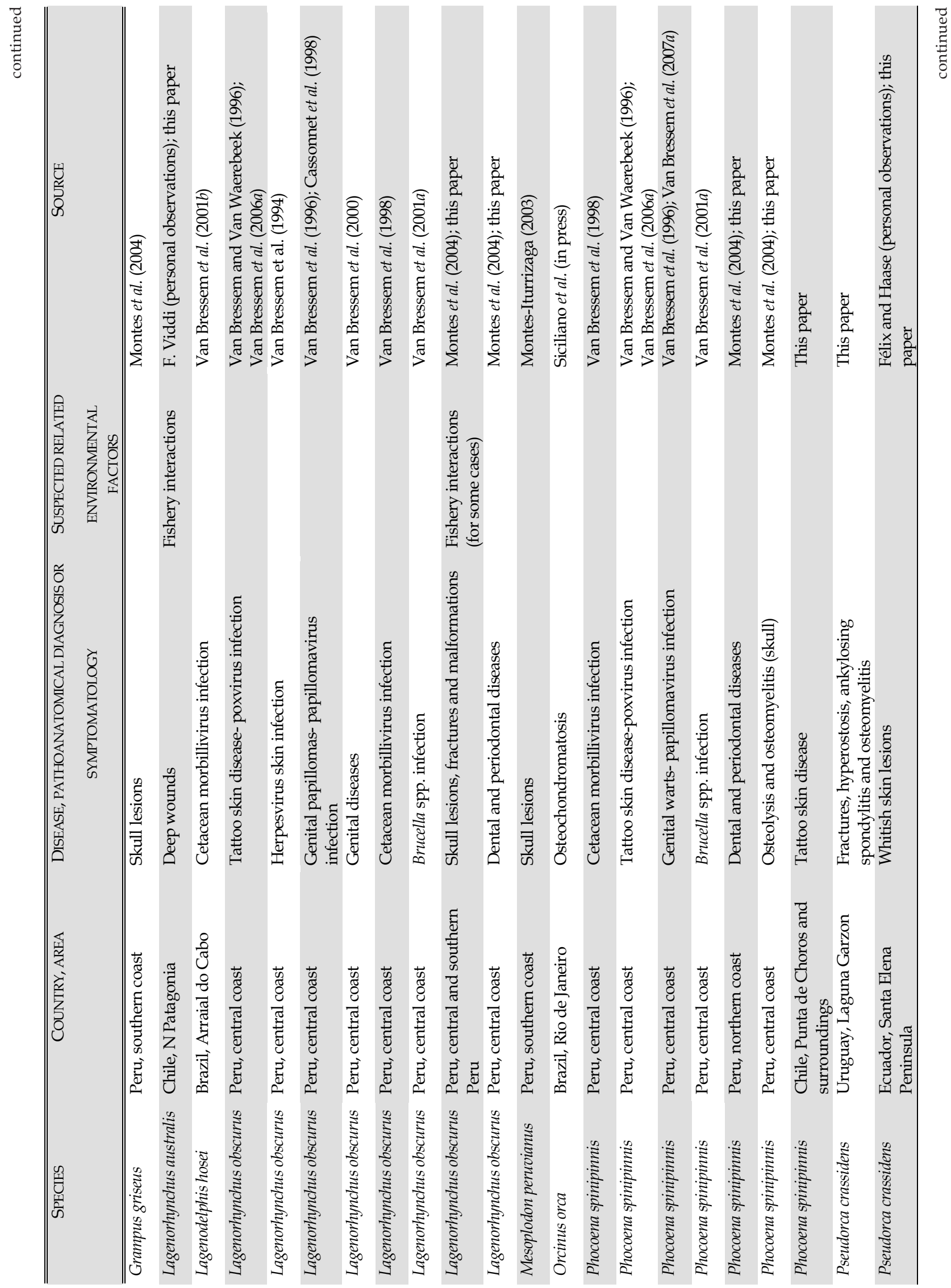




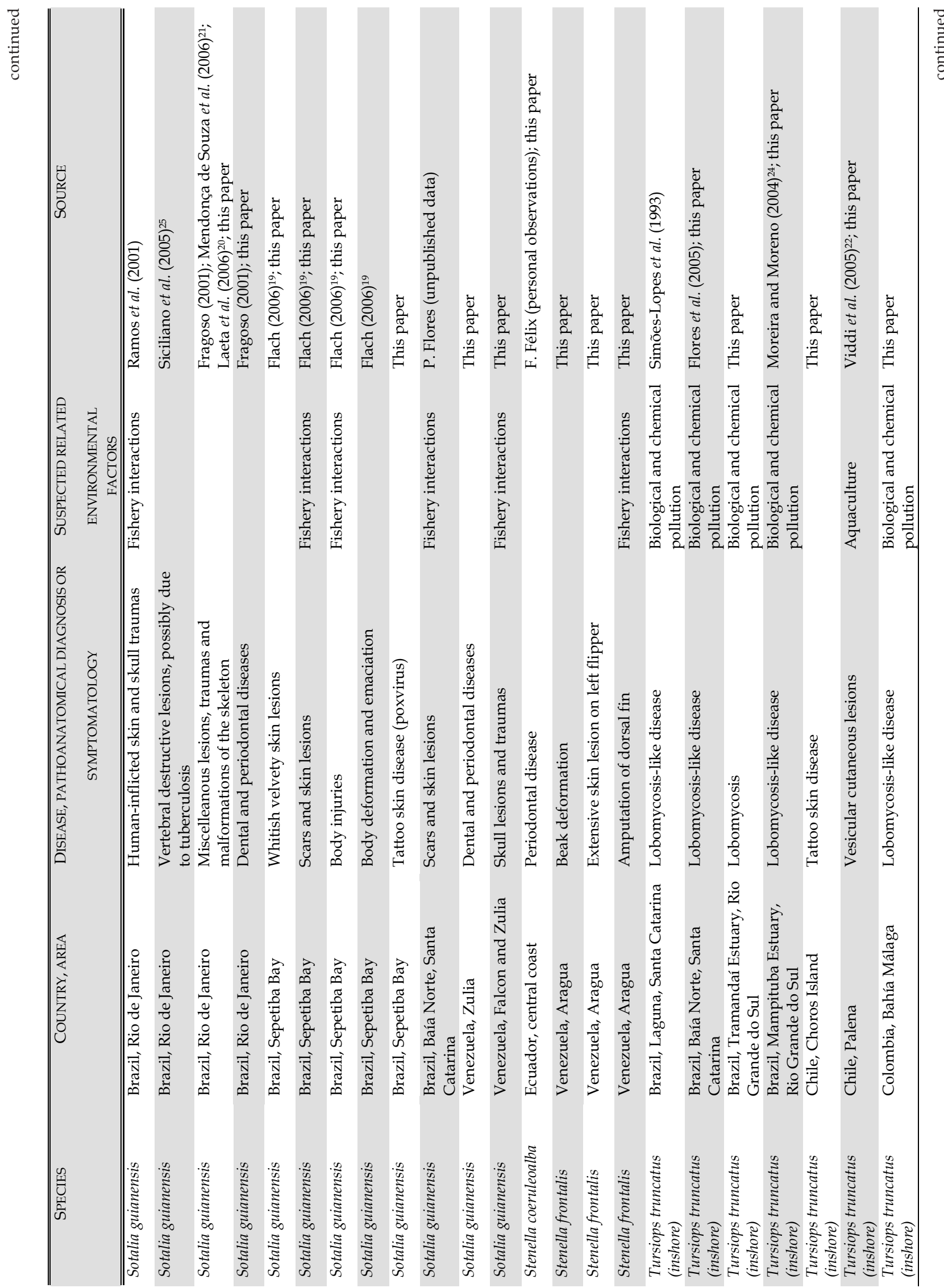




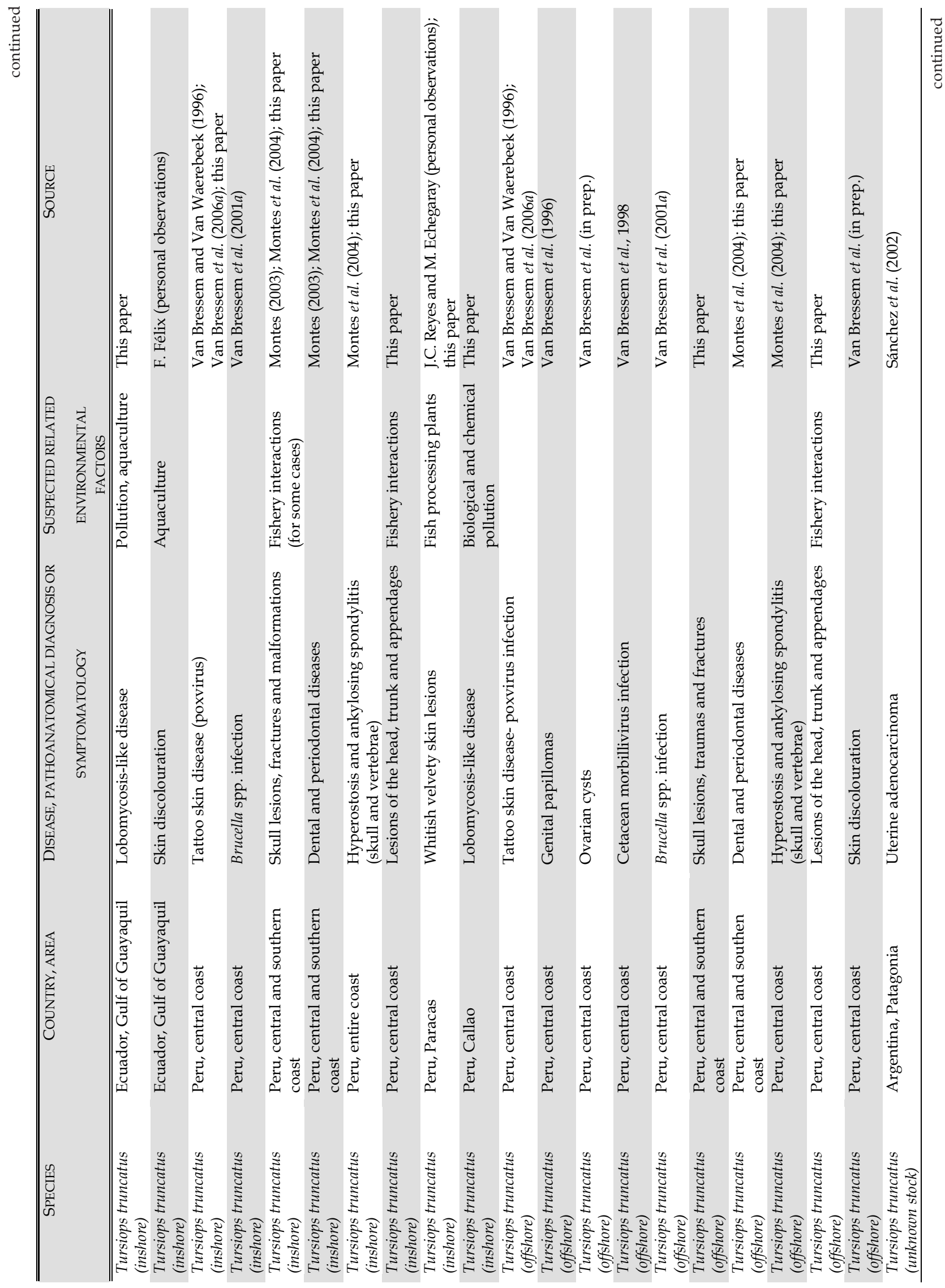




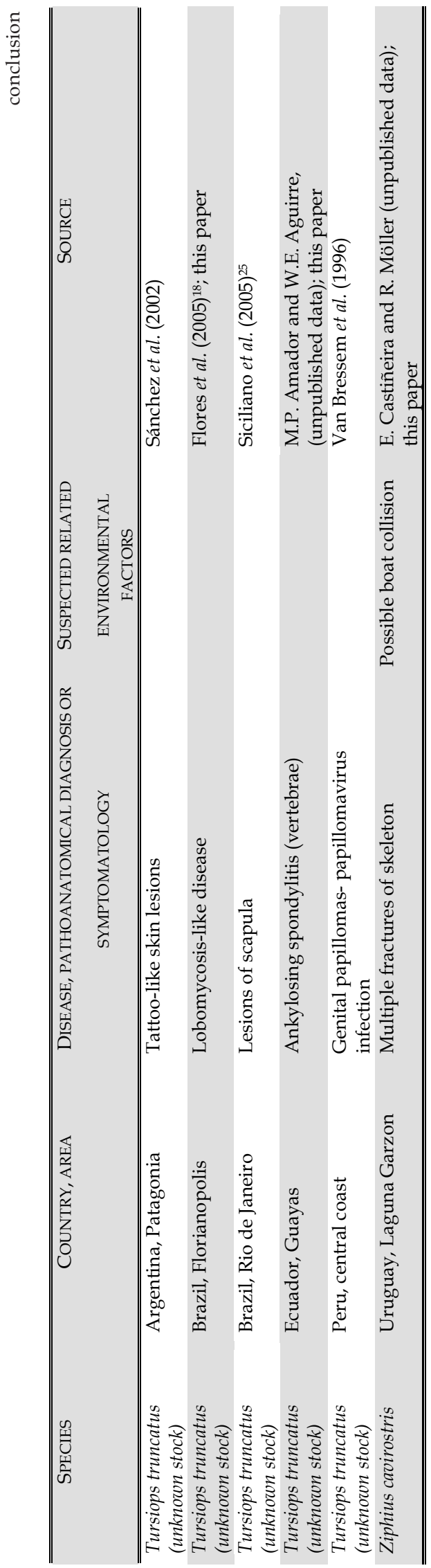

Besides their potential to kill outright, many types of fisheries may also provoke serious injuries and stress as well as influence the outcome of host-parasite interactions in the animals that survive an encounter (Van Bressem et al., 1994; 1999; 2006b; Clark et al., 2006). Polychlorinated biphenyls (PCBs) and related compounds might contribute to the severity of viral epizootics through toxicity at the level of the immune system (Aguilar and Borrell, 1994; Ross, 2002).

While a considerable number of pathology case studies have been implemented in South America, mainly over the past 15 years, no comprehensive overview of progress has so far been undertaken. In an effort to improve our understanding of pathological agents and processes that may co-determine modal health and potentially influence net recruitment and, indirectly, population size, we analysed data for 12 species of small cetaceans from the waters of eight SA countries and placed them in an epizootiological context. We further attempted to evaluate whether, and to what extent, human activities might contribute to traumata and malformations or facilitate the spread of certain infectious diseases.

\section{Material ANd Methods}

\section{Study areas and species}

In the period 1984-2007 the authors studied gross pathological evidence in about 7635 free-ranging, by-caught, and some stranded small cetaceans belonging to 12 species from the waters of Colombia, Ecuador, Peru, Chile, Argentina, Uruguay, Brazil and Venezuela (Table 2). Voucher data include images, field notes, museum specimens (skeletons) and others. Conditions of individuals studied ranged from 1 to 5 (alive to mummified or skeletal remains; Geraci and Lounsbury, 1993) but most were alive or freshly dead. A database including 55 parameters for each specimen presenting lesion(s) was compiled. The presence of suspected anthropogenic factors (fisheries, vessel collisions, fish farms, sewage and other pollution or any other type of coastal habitat encroachment) within, or in the vicinity of, each studied population's habitat was noted. Some subsets of data were previously presented at conferences (Bolaños-Jiménez and Bermúdez, 1996 23; Moreira and Moreno, 2004²4; Flores et al., 2005²; Siciliano et al., 2005²5; Viddi et al., 200522; Flach, 2006 ${ }^{19}$; Laeta et al., 2006 ${ }^{20}$; Mendonça de Souza et al., 2006 $6^{21}$ ), used in Master's theses (Fragoso, 2001; Montes-Iturrizaga, 2003) or published (Ramos et al., 2001; Montes et al., 2004; Van Bressem et al., 2006b).

\footnotetext{
${ }^{23}$ Bolaños-Jimenez, J. and Bermudez, V. (1996) Un caso de malformaciones óseas en delfin estuarino (Sotalia fluviatilis) en el Estado Zulia. Page 101 in Libro Memorias, III Congreso de Ciencias Veterinarias "Eduardo Mendoza Goiticoa", 29 September- 4 October 1996, Maracay, AR, Venezuela.

${ }^{24}$ Moreira, M.B and Moreno, I.B. (2004) Patologia epitelial em Tursiops truncatus no Rio Mampituba, sul do Brasil. Page 92. in Abstracts, XI Reunión de Especialistas em Mamíferos Acuáticos del América Del Sur, 12-17 September, 2004, Quito, Ecuador.

${ }^{25}$ Siciliano, S., Hassel, L.B., Alves, V.C., Dittmar, K. and Mendonça de Souza, S.M.F. (2005) Pathological findings in the skeletons of small cetaceans from Rio de Janeiro, Brazil. Page 51 in: Abstracts, $1^{\text {st }}$ Paleopathology Association Meeting in South America, 25-29 July 2005, Escola Nacional de Saúde Pública/ FIOCRUZ, Rio de Janeiro, RJ, Brazil.
} 


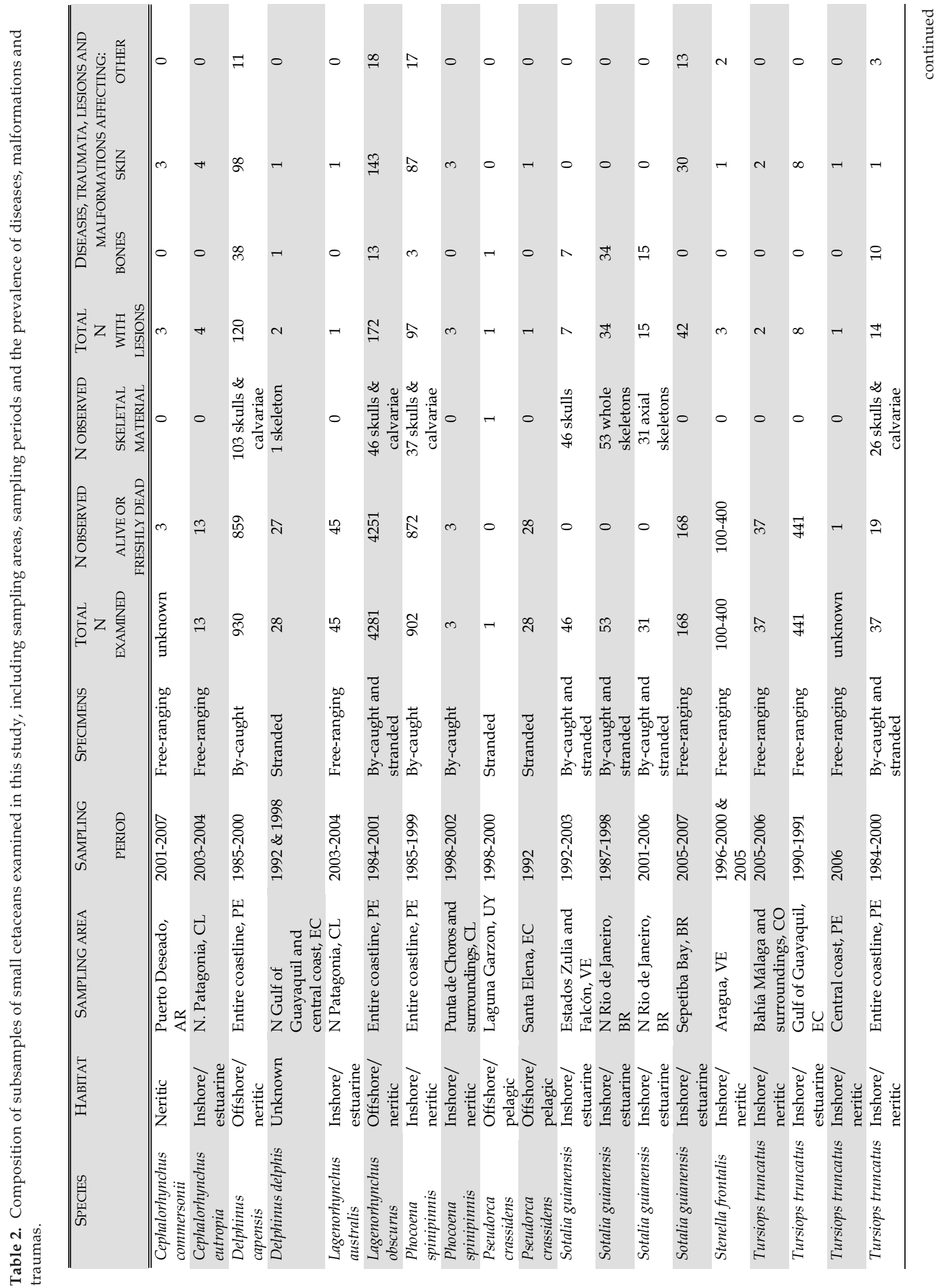




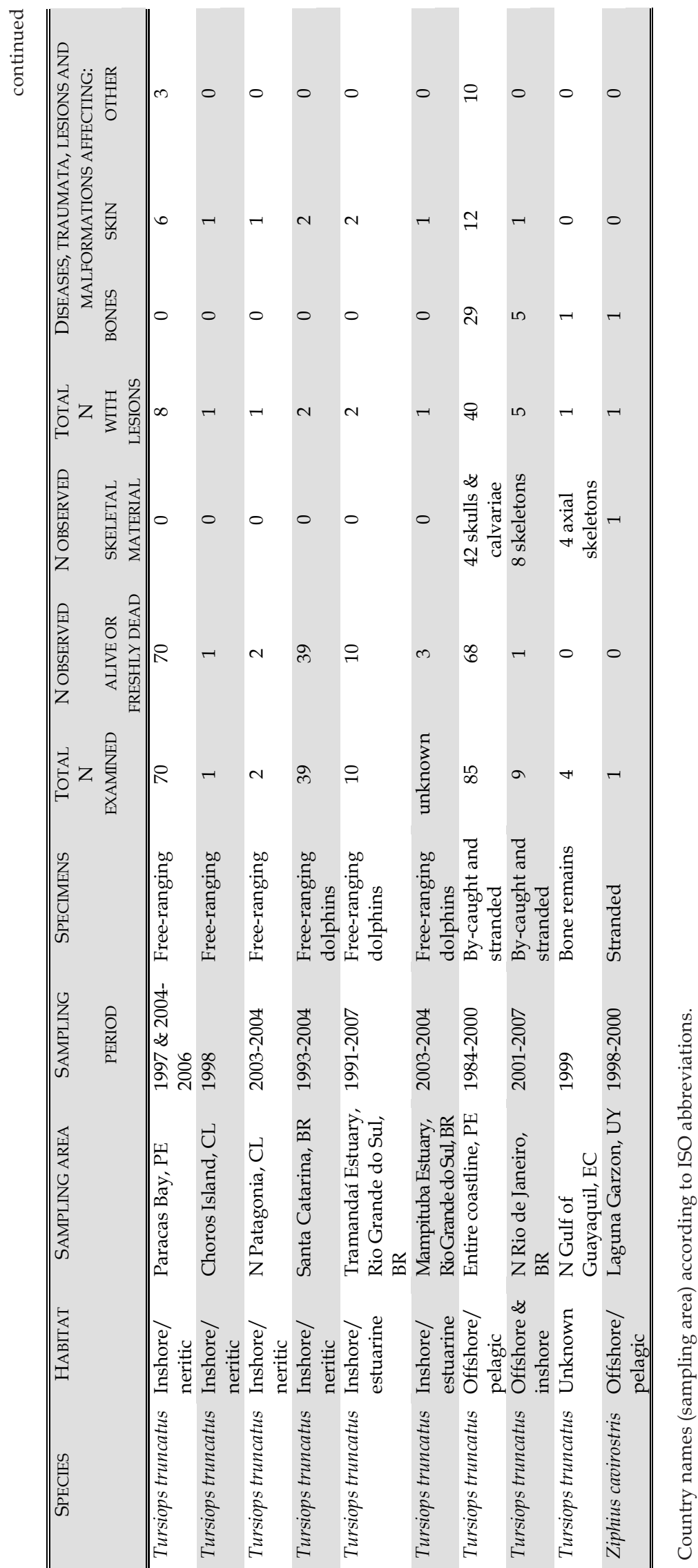




\section{Skeletal material}

The skulls and skeletons of 399 dolphins and porpoises from Ecuador, Peru, Uruguay, Brazil and Venezuela (Table 2) were examined for the presence of osteopathology and abnormalities. Particular attention was paid to Crassicaudiasis, apparently irreversible, basket-like cranial lesions caused by Crassicauda spp. nematodes because of high potential for pathogenicity and mortality (e.g. Perrin and Powers, 1980; Raga et al., 1982; Dailey, 1985). Skeletal material is deposited at cetacean reference collections including the Museo de Delfines (Pucusana, Peru), Áreas Costeras y Recursos Marinos (ACOREMA, Pisco, Peru), Grupo de Estudos de Mamíferos Marinhos da Região dos Lagos (GEMMLagos, Brazil), Universidade Estadual do Norte Fluminense-LCA (Brazil), Museu de Zoologia da Universidade de São Paulo (Brazil), Museo de Ballenas (FEMM, Ecuador), Museo de la Estación Biológica Rancho Grande (EBRG, Ministerio del Ambiente MINAMB, Venezuela) and Exhibición Museo del Mar (Maldonado, Uruguay).

Individuals were considered cranially mature when presenting advanced fusion in the frontal-supraoccipital or premaxillary-maxillary sutures or, if these were damaged, in at least two of five other indicative cranial sutures (Van Waerebeek, 1992; 1993).

\section{Recently dead specimens}

Carcases of 6128 small cetaceans from Ecuador, Peru, Chile and Brazil were examined, predominantly under field conditions (e.g. fish markets and beaches), for macroscopical lesions, malformations and cutaneous diseases. Observations were opportunistic in Peru until 1990. Dedicated research in 1993-95 allowed practically unbiased prevalence rates to be estimated for by-caught dusky dolphins (Lagenorhynchus obscurus), offshore and inshore common bottlenose dolphins (Tursiops truncatus), long-beaked common dolphins (Delphinus capensis) and Burmeister's porpoises (Phocoena spinipinnis). Sexual maturity was determined, in females, from the presence of at least one corpus luteum or corpus albicans in one of the ovaries, or evidence of lactation or pregnancy (visible foetus); in males, if seminal fluid was detected macroscopically in at least one freshly cut epididymis. When sexual maturity status could not be determined directly, it was inferred based on an approximation for the mean standard body length (SL) at sexual maturation for these populations (Van
Waerebeek et al., 1990; Van Waerebeek, 1992; Reyes and Van Waerebeek, 1995; Van Bressem et al., 2006b).

\section{Free-ranging dolphins}

The prevalence of evident dermatologic disease, gross body deformations and traumata, including extensive scarring or mutilation, was studied in a minimum of 1196 free-ranging dolphins (Table 2) from images taken during photo-identification surveys from small boats or from shore (Félix, 1997; Bolaños-Jiménez et al., 1998; 2007; Sanino and Yáñez, 2001; Reyes et al., 2002 26; Ott, 2004; Flores et al., 200518; Viddi et al., 2005²2; Flach, 2006 ${ }^{19}$; Flores and Fontoura, 2006). Dolphins were individually identified from natural marks (Würsig and Jefferson, 1990). The maturity class (calf, juvenile, adult) of T. truncatus from Colombia's Bahía Málaga (and surroundings), Chile, the Gulf of Guayaquil (Ecuador) and southern Brazil, of Chilean dolphins (Cephalorhynchus eutropia) and Guiana dolphins (Sotalia guianensis) from Sepetiba Bay, Brazil, was estimated from relative body size and behavioural clues (Wells et al., 1980; Shane, 1990) or from the period of residence. Maturity of Atlantic spotted dolphins (Stenella frontalis) from Venezuelan waters was estimated from the degree of body spotting (Herzing, 1997). Dedicated surveys to assess the presence of skin conditions and traumata were conducted in C. eutropia, Peale's dolphin (Lagenorhynchus australis) and T. truncatus from Chile as well as in S. guianensis from Sepetiba Bay (Viddi et al., 200522; Flach, 2006 ${ }^{19}$ ). Populations of inshore $T$. truncatus from Paracas (Peru), the Gulf of Guayaquil (Ecuador), and Rio Grande do Sul and Santa Catarina (Brazil) have been the objects of long-term field research (Oliveira et al., 199627; Félix, 1997; Reyes et al., 2002 ${ }^{26}$; Flores et al., 2005 ${ }^{18}$; Flores and Fontoura, 2006). In these cases, prevalence of diseases and traumata could be estimated with precision.

\section{Sexual and ontogenetic variation}

With sample sizes permitting, we examined whether disease prevalence varied with sex and sexual or cranial maturity as a proxy for age. Prevalence refers to the amount of lesions and disease in samples and subsamples at the time of examination, without distinction between old and new cases (Thrusfield, 1986). Significance of differences in prevalence $(\leq 0.05)$ was verified with chi-square contingency tests or one-tailed Fisher's exact tests (Swinscow, 1981).

\footnotetext{
${ }^{26}$ Reyes, J.C., Echegaray, M. and De Paz, N. (2002) Distribución, comportamiento y conservación de cetáceos en el área Pisco Paracas. Pages 136-144 in Mendo, J. and Wolff, M. (Eds). Memorias I Jornada Científica Reserva Nacional de Paracas. Universidad Nacional Agraria, Lima, Peru.

${ }^{27}$ Oliveira, L.R., Ott, P.H, Borges-Martins, M. and Danilewicz, D. (1996) Fotoidentificação da população de botos (Tursiops truncatus) do estuário do Rio Tramandaí, RS, Brasil. p.250 in XXI Congresso Brasileiro de Zoologia, 1996, Porto Alegre, Brasil.
} 


\section{Results}

Cutaneous diseases, wounds, scars and traumata were observed in large numbers of small cetaceans from Colombia, Ecuador, Peru, Chile, Argentina, Brazil and Venezuela (Table 2). For instance, all populations and ecotypes of T. truncatus from South America exhibited skin diseases. Due to the very large amount of data we have limited this preliminary analysis to diseases that are likely of highest concern in relation to environmental factors and anthropogenic effects.

\section{Cutaneous diseases}

\section{$>$ Tattoo skin disease}

Tattoo skin disease (TSD) is characterized by very typical, irregular, grey, black or yellowish, stippled lesions that may occur on any part of the body but show a preferential corporal distribution depending on the species (Van Bressem and Van Waerebeek, 1996). The prevalence of tattoo positive dolphins and porpoises from the SE Pacific and SW Atlantic is presented in Table 3. TSD is highly prevalent and likely endemic in Peruvian small cetaceans and, at least in delphinids, affects predominantly juveniles. The earliest confirmed case in Peru is a D. capensis landed in January 1986 (Van Bressem et al., 2006b). The apparent low prevalence in inshore T. truncatus from the Bay of Paracas (Peru) is likely related to the fact that photo-identification images permitted only dorsal parts of the body to be examined and that tattoos may be difficult to spot on the dark grey skin. The disease is also present in the short-beaked common dolphin (Delphinus delphis) from Ecuador, P. spinipinnis and T. truncatus from Punta de Choros and surroundings (Chile) and, possibly, in the Commerson's dolphin (Cephalorhynchus commersonii) from Argentine Patagonia. In inshore C. eutropia from southern Chile and S. guianensis from Sepetiba Bay $\left(23^{\circ} \mathrm{S}, 44^{\circ} \mathrm{W}\right)$, southern Rio de Janeiro state (Brazil), tattoos were observed only in adults (Figure $1 a, b)$. However, 167 of the 168 S. guianensis photo-identified during this study were adults. Both active tattoos (dark gray or black stippled lesions, Figure $1 b$ ) and tattoo remains (light gray marks, Figure 1c) were seen in the Sepetiba dolphins. TSD was not detected in 91 S. guianensis accidentally caught off northern Rio de Janeiro (RJ) in 1988-2004 (Van Bressem et al., 2003a; Di Beneditto, pers. obs.) but may represent a threat for this population through contacts with dolphins from southern RJ.

\section{$>$ Rounded cutaneous lesions}

Large rounded lesions with an orange or dark outline and a light inner colour were seen in a C. commersonii from Argentine Patagonia in 2001 and a C. eutropia calf from southern Chile in 2003 (Figures 2a,b). Their irregular rounded shape evoked superinfected tattoo lesions seen, for instance, in a T. truncatus calf from the
Sado Estuary, Portugal (Van Bressem et al., 2003b) but their aetiology is unknown. The lesions were extensive in both dolphins and the calf apparently died six weeks after the lesions were first noted. A similar but much smaller orange, rounded skin mark was seen in another C. commersonii from Puerto Deseado, Argentina while at least six dark orange skin marks with an irregular outline were detected in a S. guianenis from Sepetiba Bay. In these two cases the lesions also showed the irregular, rounded shape characteristic for tattoo-like lesions. Diatoms have been found in orange skin marks on harbour porpoises (Phocoena phocoena) from Washington state, northeastern Pacific (Norman et al., 2004) and could have superinfected existing lesions in SA small cetaceans.

\section{$>$ Whitish velvety lesions}

Whitish lesions with a velvety appearance and often associated with unrelated wounds, scars and tooth rakes were observed on the beak, back, dorsal fin and flukes of inshore T. truncatus from the Bay of Paracas, S. guianensis from Sepetiba Bay and a false killer whale (Pseudorca crassidens) stranded in Santa Elena, Ecuador (Table 3; Figures $3 a, b, c, d$ ). In two photo-identified common bottlenose dolphins in the Bay of Paracas in 2004-2005, dorsal fin skin lesions ulcerated, exposing the underlying connective tissues, and subsequently cicatrised over a period of 2-6 months (Figures $3 c, d$ ).

\section{$>$ Lobomycosis-like disease (LLD)}

Whitish to slightly pink, verrucous lesions, often in pronounced relief, that may ulcerate and evoke lobomycosis (Migaki et al., 1971) were observed in freeranging inshore T. truncatus from Colombia, Ecuador, Peru and Brazil (Table 3; Figures $4 a, b, c, d$ ). The lesions were either disseminated or localized and affected the beak, dorsal fin, dorsum, flanks, belly, tailstock and flukes. In Bahía Málaga and surroundings, Colombia, LLD was first observed in two adults from a group of six in August 2005. Two dolphins with LLD, possibly the same as those seen in 2005, were sighted in February 2006 among a group of seven. In addition, single dolphins with LLD were repeatedly photographed in the period February-October 2006 among groups of 4 to 37 individuals (Figure $4 d$ ). Two mature dolphins from Tramandaí estuary, southern Brazil, known since 1991, developed LLD over several years. The lesions were observed on the dorsal fin of the first one in May 1999. The dolphin was last sighted and photographed in August 2003 (Hoffmann, 2004), and probably died since. The second dolphin (GEMARS 1259), a male, was first seen with LLD on the rostrum in December 2002. It died in November 2005 with widespread lesions (Figure 4b). Histological examination confirmed the visual diagnostic of lobomycosis (GEMARS, unpublished data). In the estuary of Mampituba river, southern Brazil, about $80 \mathrm{~km}$ north of Tramandaí, another T. truncatus was first noticed with LLD on the flanks in September 2003. 


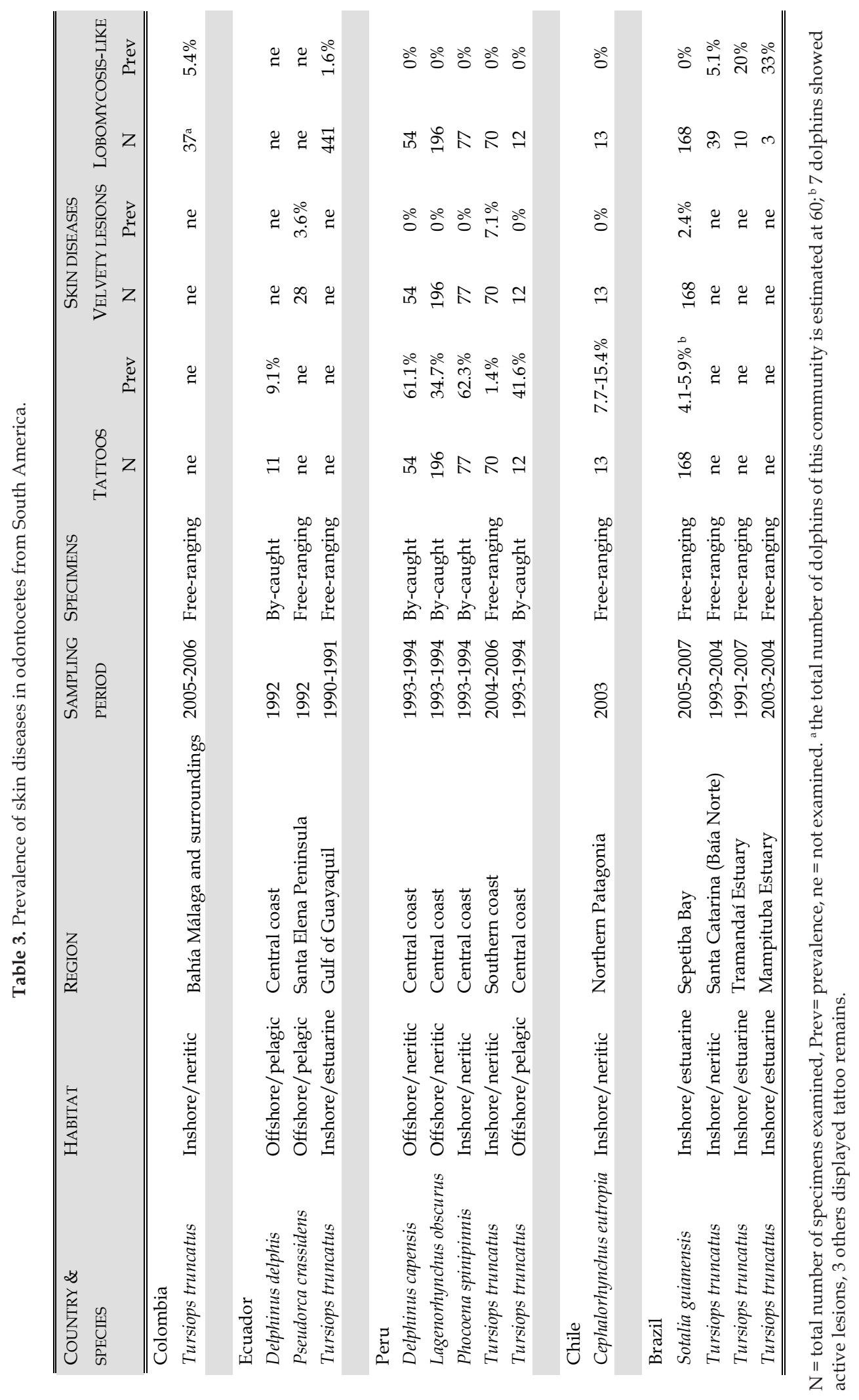




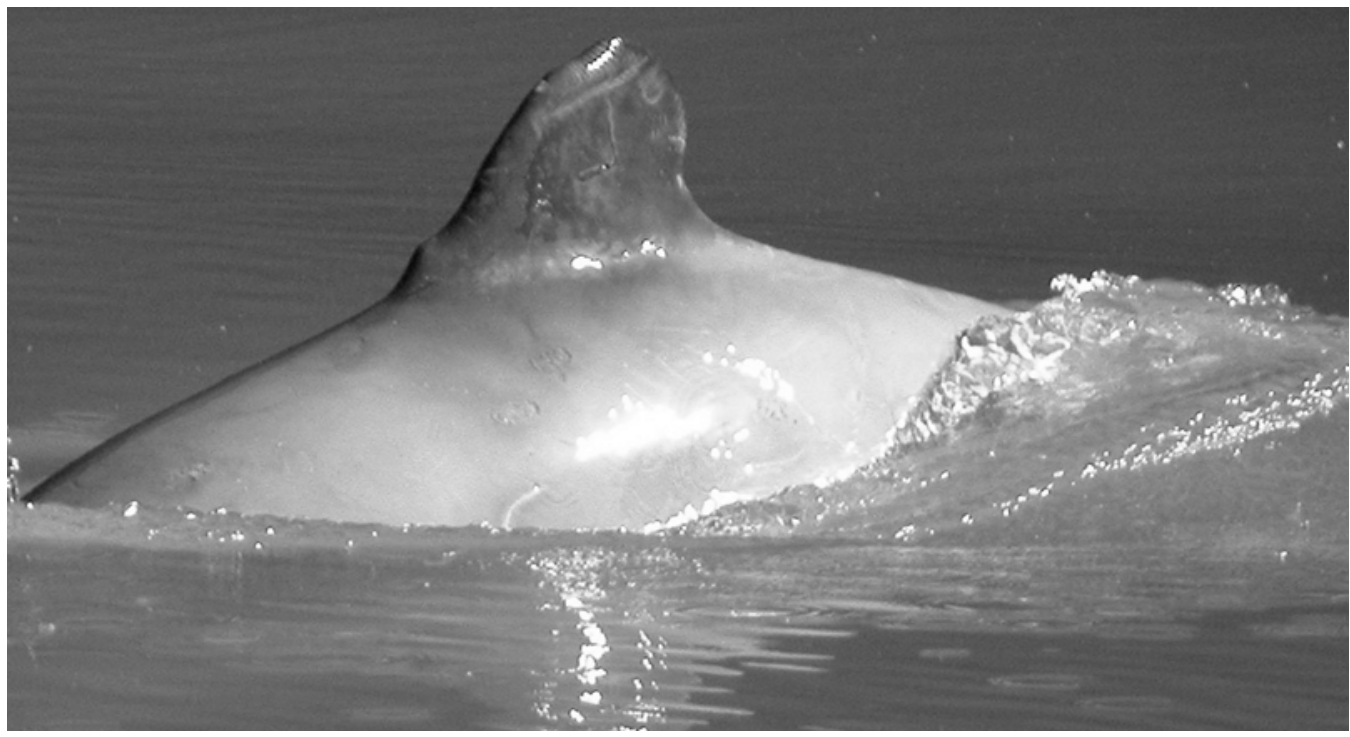

Figure 1a. Tattoo lesions in an adult Cephalorhynchus eutropia (CEU-012) from southern Chile.

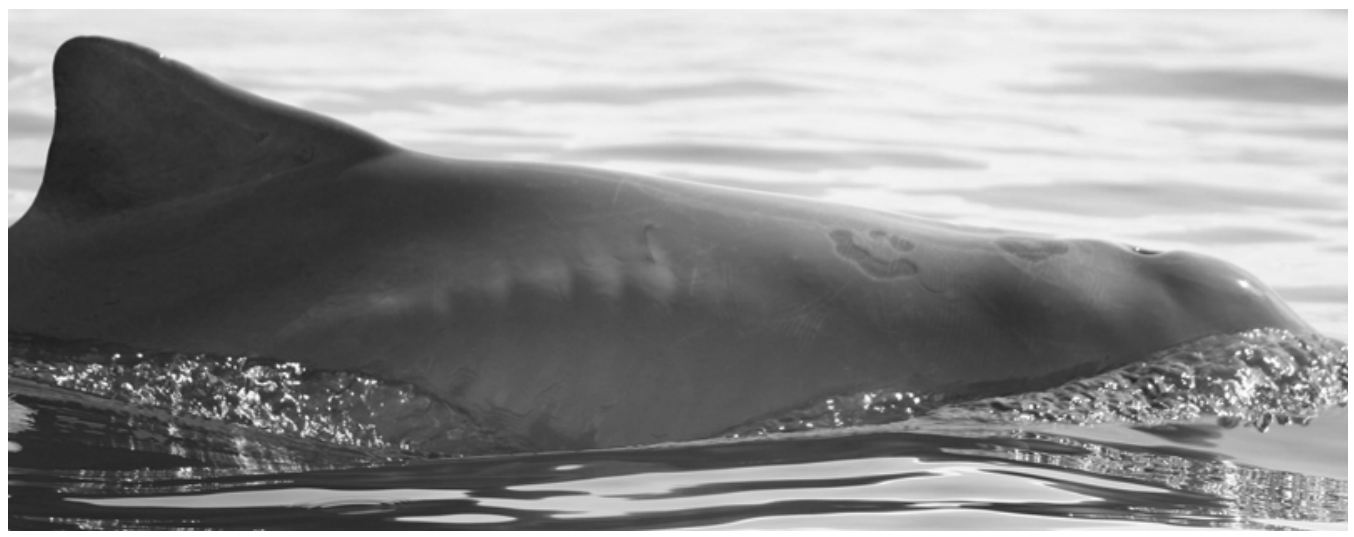

Figure 1b. Tattoo lesions and emaciation in an adult Sotalia guianensis (SEP-007) from Sepetiba Bay (Brazil).

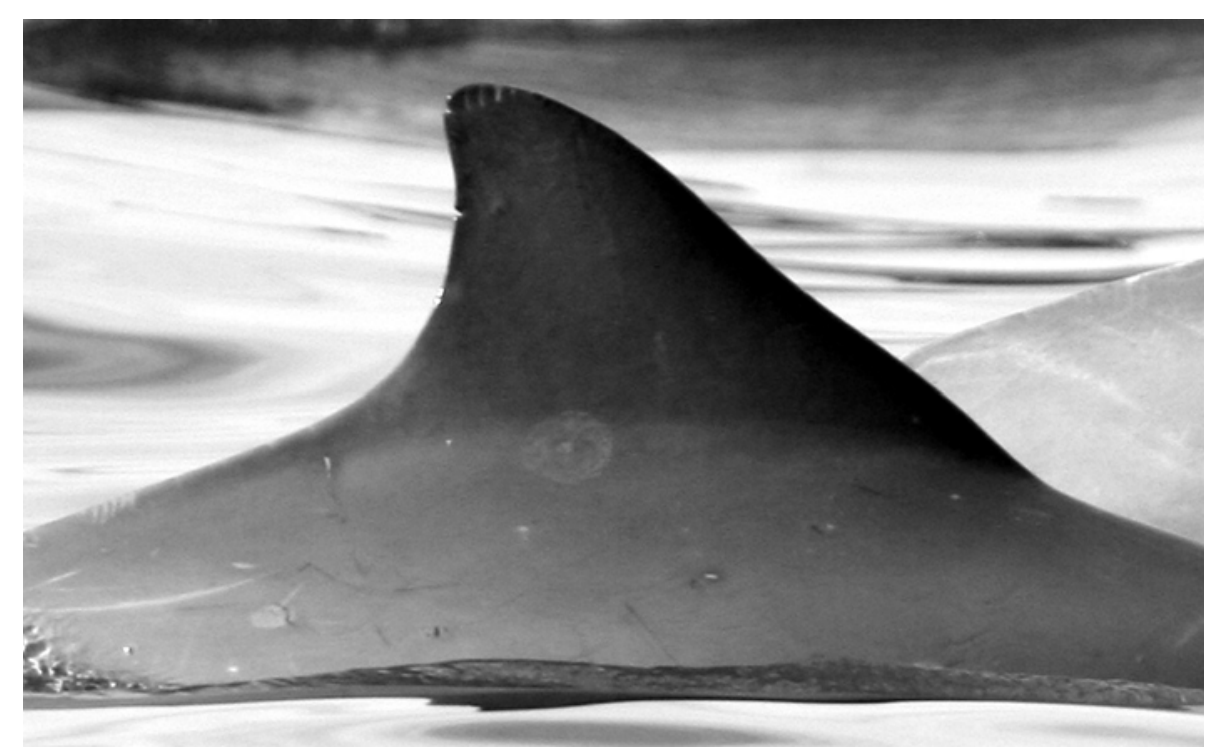

Figure 1c. Tatoo remains on the dorsal fin and back of a Sotalia guianensis (SEP-021) from Sepetiba Bay (Brazil). 


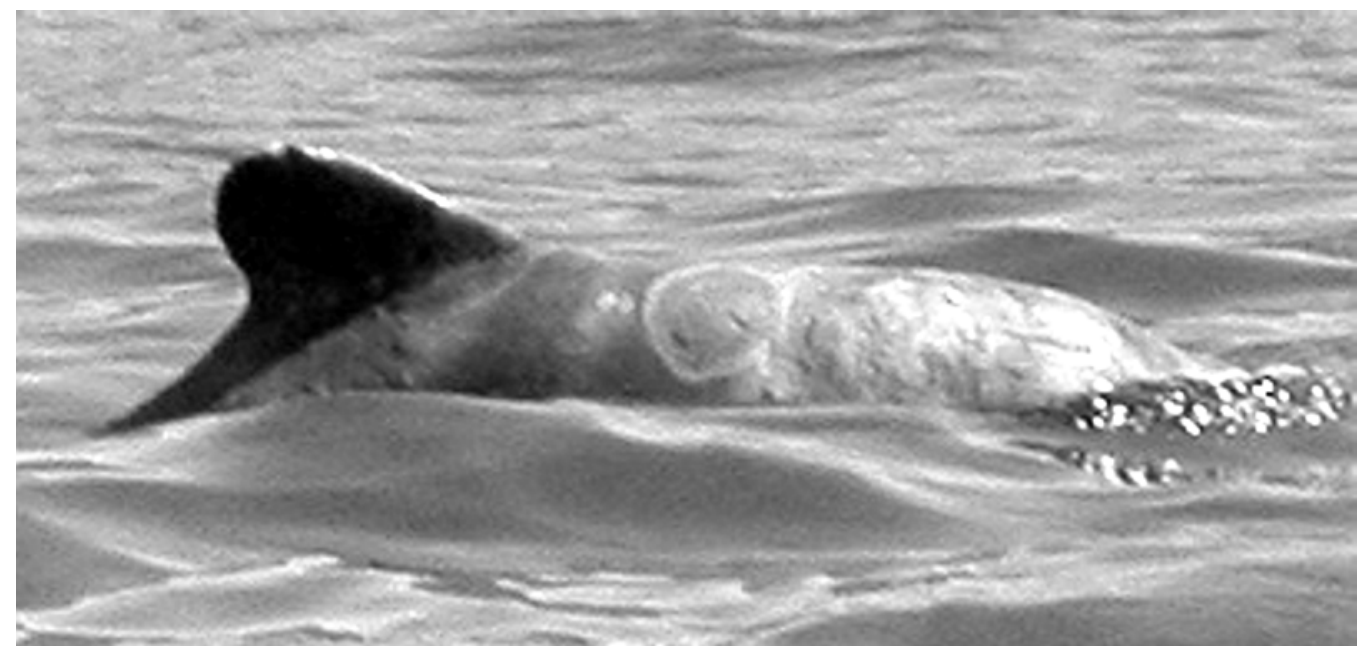

Figure 2a. Large, rounded lesions in a calf Cephalorhynchus eutropia (CEU-37) from northern Patagonia (Chile).

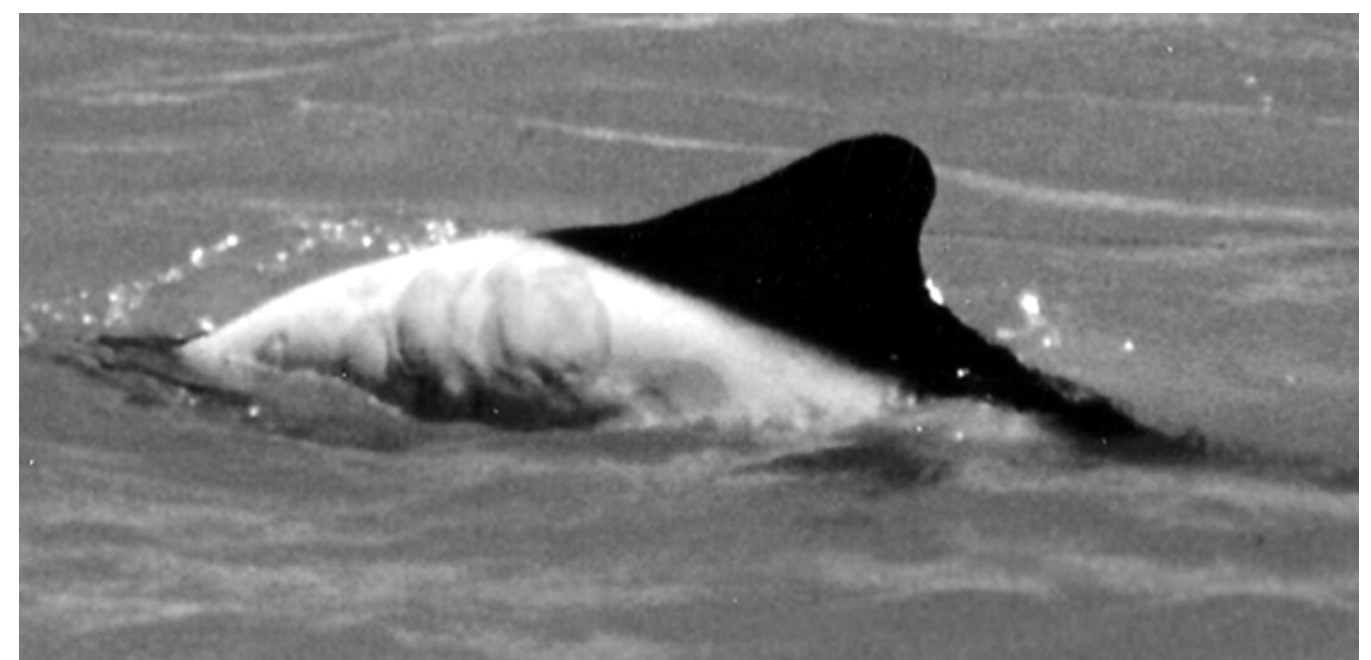

Figure 2b. Large rounded lesions in a Cephalorhynchus commersonii (CCO-SN) from Patagonia (Argentina).

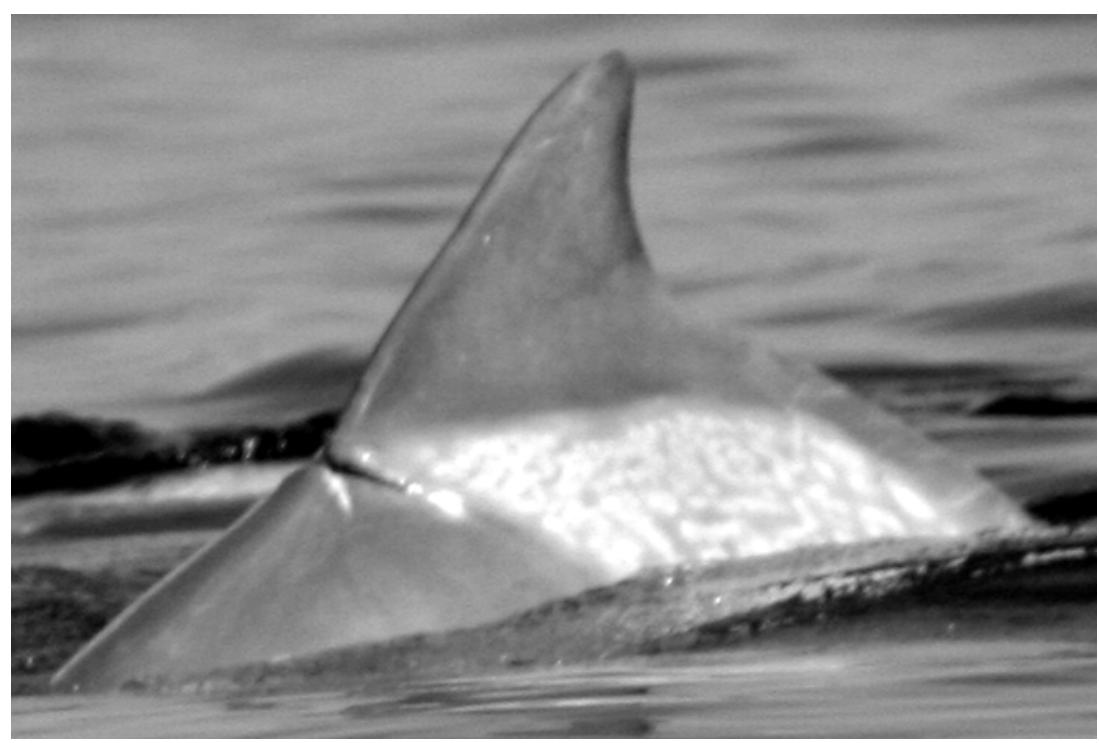

Figure 3a. Whitish, velvety lesions associated with a deep wound in an adult Sotalia guianensis (SEP-033) from Sepetiba Bay (Brazil). 


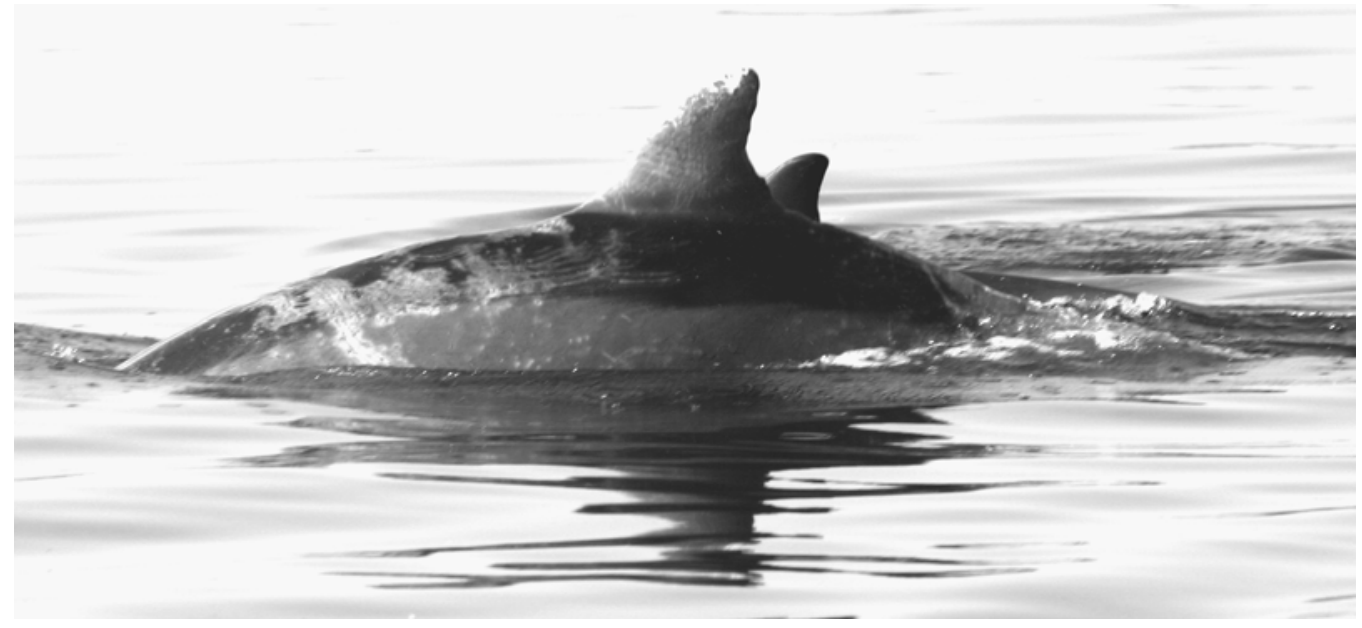

Figure 3b. Whitish, velvety lesions associated with scars in an inshore Tursiops truncatus (PBD-060) from Paracas Bay (Peru).

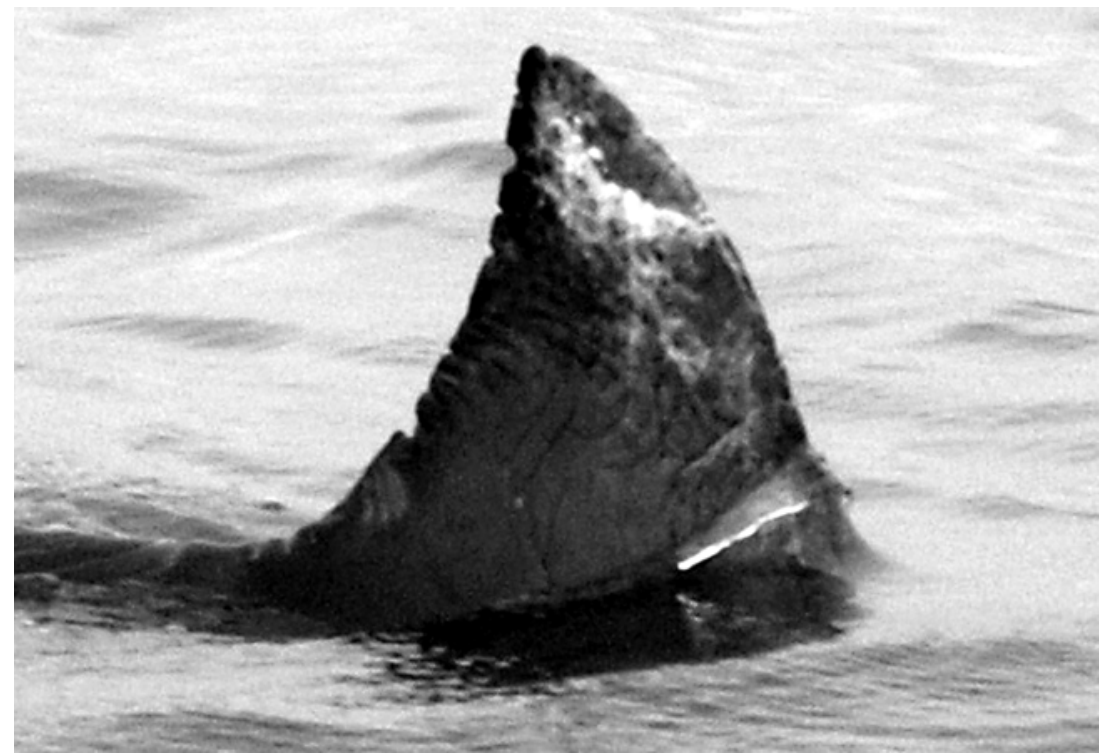

Figure 3c. Ulcerated whitish lesions on the dorsal fin of an inshore Tursiops truncatus (PBD-015) from Paracas Bay (Peru) on 10 November 2004.

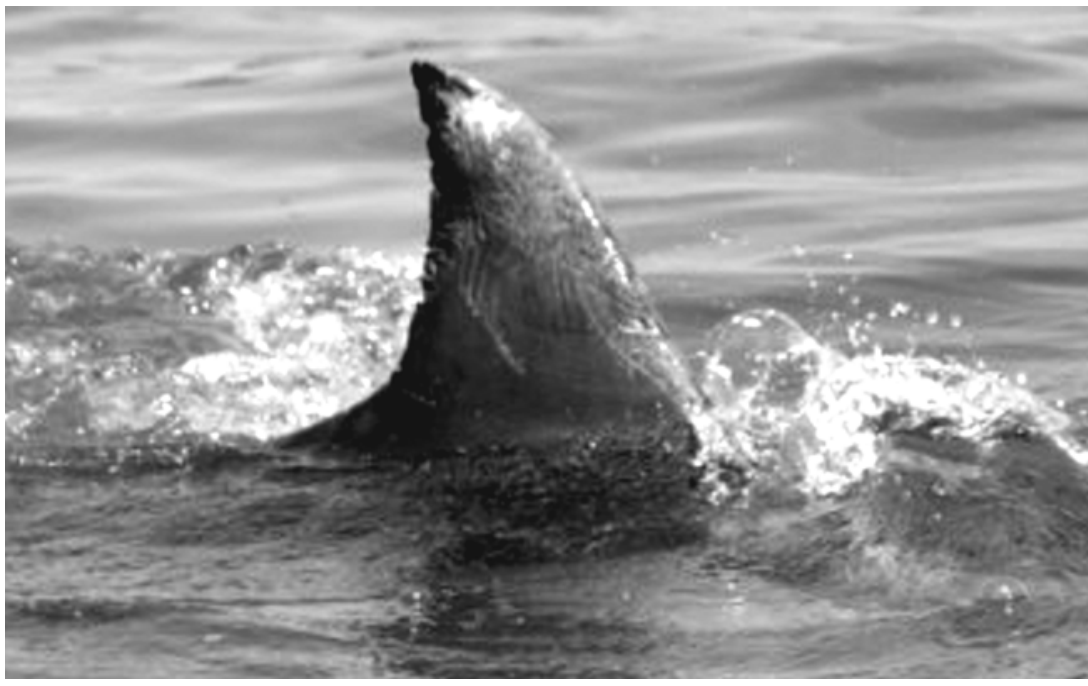

Figure 3d. Healed lesions on the dorsal fin of an inshore Tursiops truncatus (PBD-015) from Paracas Bay (Peru) on 18 January 2005. 


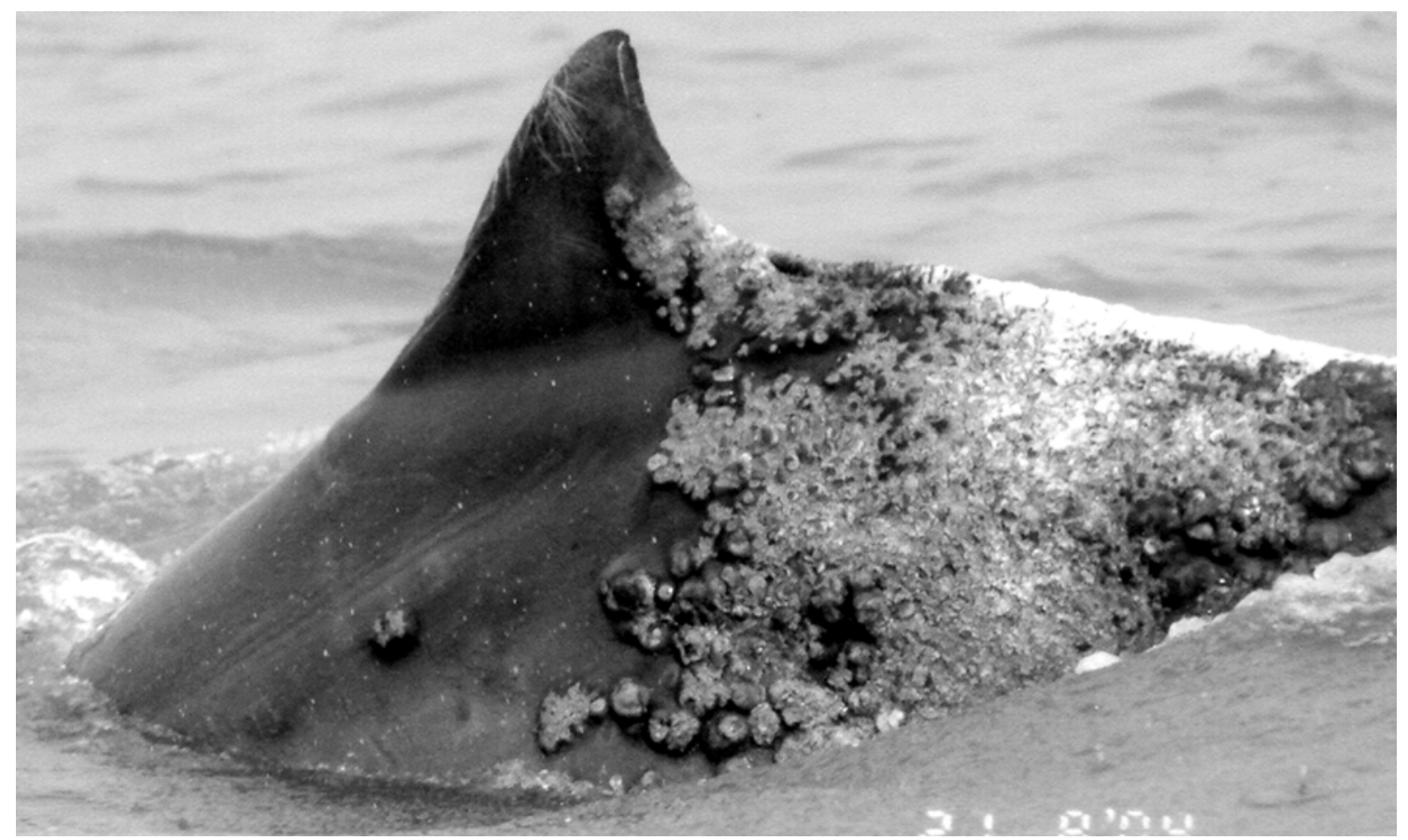

Figure 4a. Lobomycosis-like disease in an adult, inshore Tursiops truncatus (TPBN-03) from Baia Norte, Santa Catarina (Brazil).

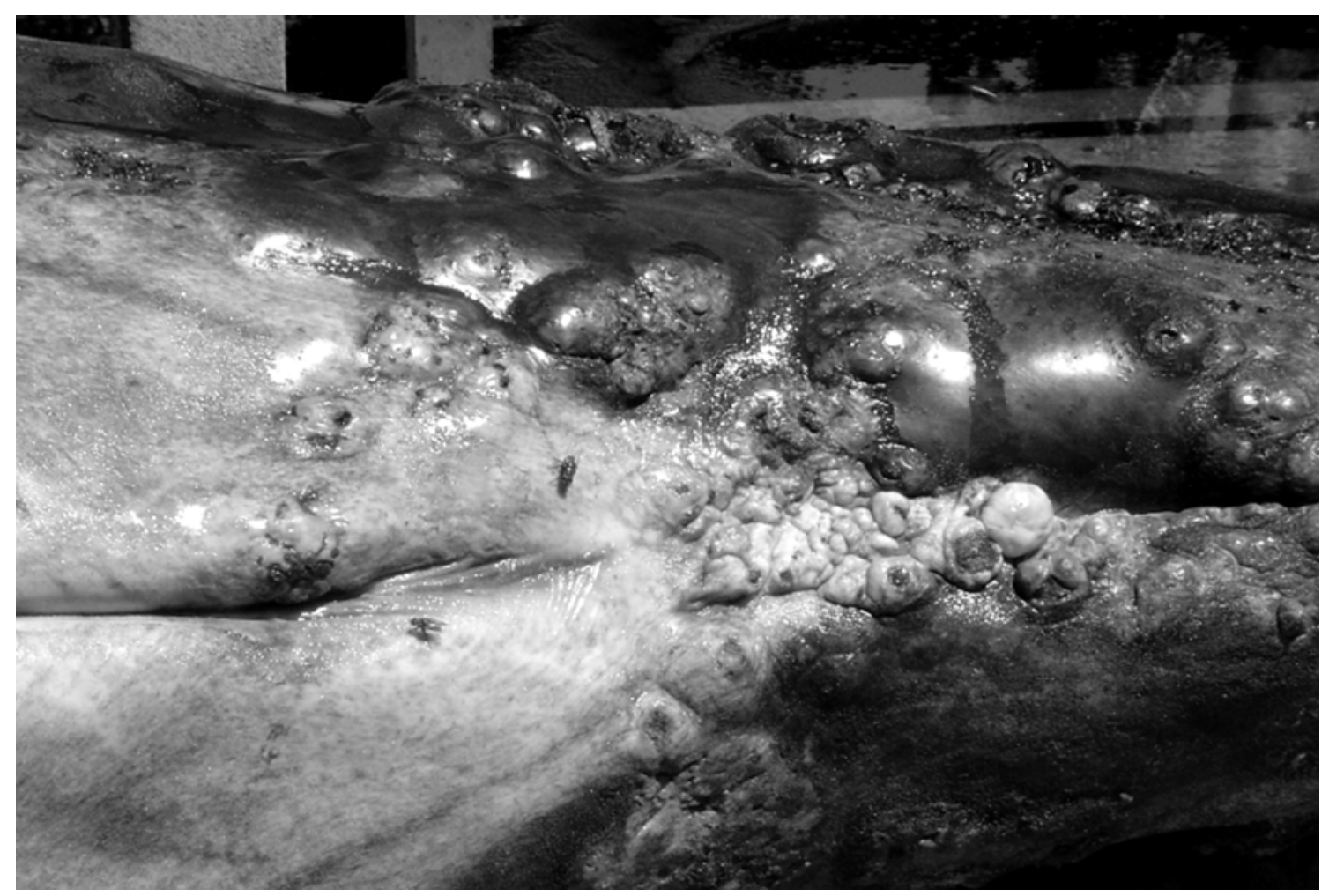

Figure 4b. Lobomycosis in an adult male, inshore Tursiops truncatus (GEMARS-1259) from the Tramandaí Estuary (Brazil). 

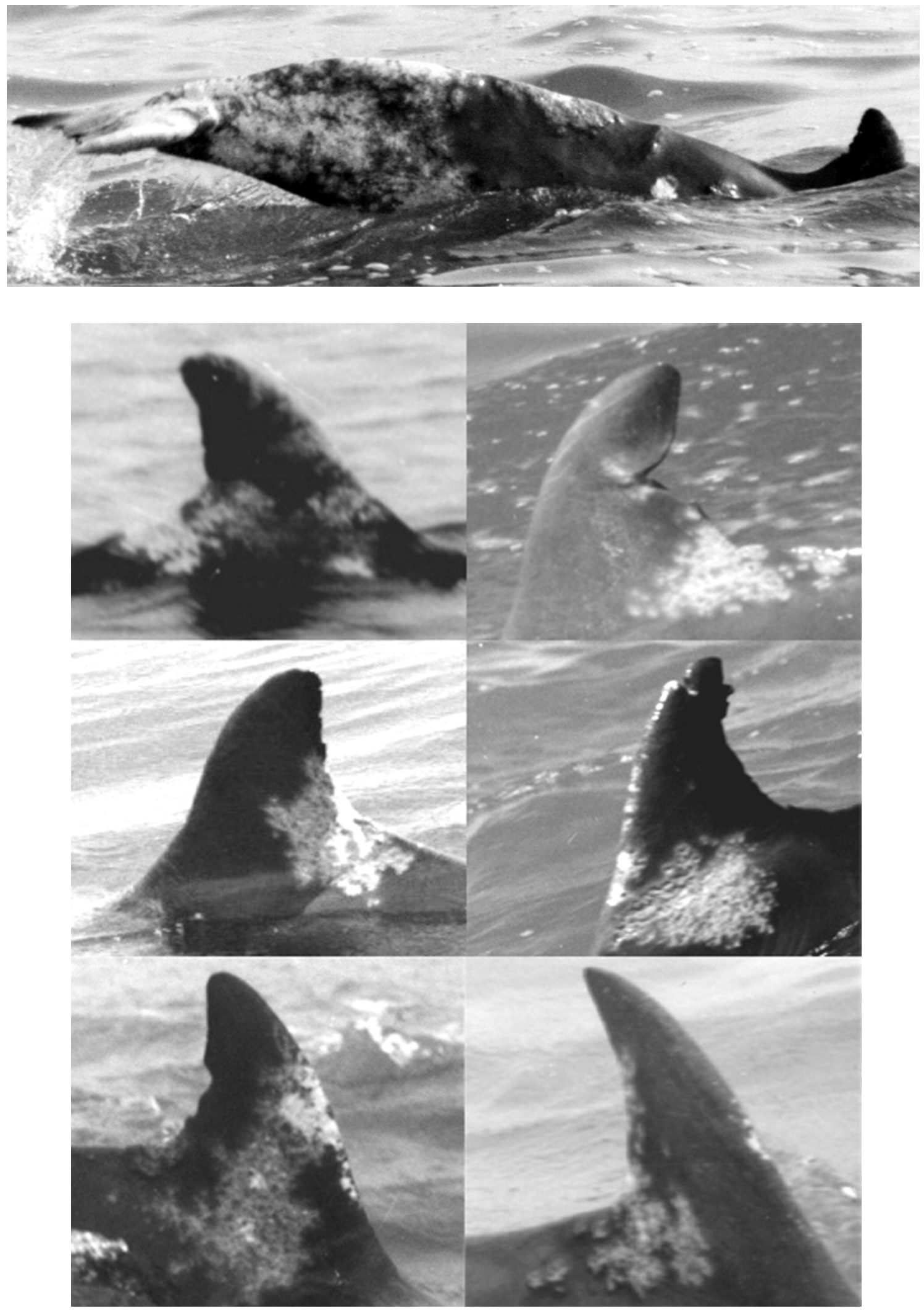

Figure 4c. Lobomycosis-like disease in estuarine Tursiops truncatus (FEMM-22, -148, -149, -160, -282, -318 and-319) from the Gulf of Guayaquil (Ecuador) 


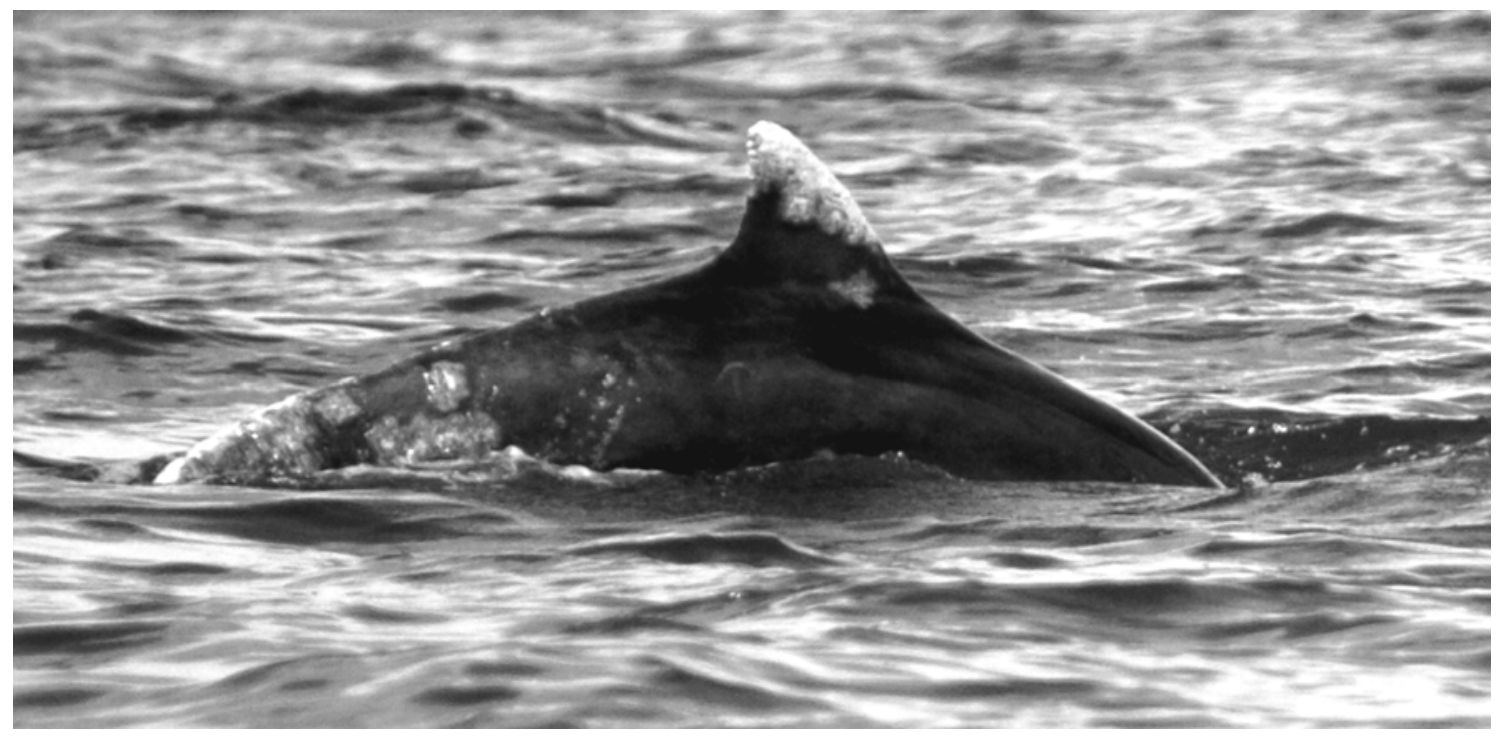

Figure 4d. Lobomycosis-like disease in an inshore Tursiops truncatus FYUB-BM-0206G1-1 from Bahía Málaga and surroundings (Colombia).

It presented widespread lesions on the dorsum in March 2004 (Moreira and Moreno, 2004 ${ }^{24}$ ). Further north two T. truncatus from Baía Norte also had LLD. In one of them the disease lasted at least 20 months (Flores et al., 2005 ${ }^{18}$ ). One T. truncatus sighted off Callao, Peru's main port, in December 2006 showed extensive lobomycosis-like lesions and ulceration of the dorsal fin. Importantly, despite observations at hundreds of both captured and free-ranging individuals by CEPEC and ACOREMA scientists along the entire Peruvian coast (Reyes et al., 200226; unpublished data), this condition was never seen in the period 1984-2005. Hence, LLD is considered an emerging disease in Peru.

\section{$>$ Vesicular lesions}

Vesicles were noticed in an adult female T. truncatus (Figure 5) from Palena, Chile in December 2003. Several ulcerated lesions were observed on the flanks of a $T$. truncatus stranded in RJ in March 2007. Ulcerative dermatitis caused by Aeromonas hydrophila was described in T. truncatus (Cusick and Bullock, 1973). A calicivirus (cetacean calicivirus 1) caused ulcerative vesicular lesions in two captive Atlantic T. truncatus (Smith et al., 1983).

\section{Miscellaneous traumata}

Wounds and extensive traumata affected the head, trunk and appendages of different species and populations (Tables 4 and 5). A large percentage of the cutaneous wounds, cuts, large or deep scars and other traumata observed in all populations studied was likely related to net entanglements and to a lesser extent to boat collisions (Tables 4 and 5). In 17 cases involving T. truncatus (both ecotypes, Peru), $P$. spinipinnis (Peru), S. guianensis (Brazil) and Stenella frontalis (Venezuela) the dorsal fin, flippers and flukes were severely injured resulting in partial or complete amputations and deformations (Figure $6 a$; Table 5). Interactions with fisheries are thought to have caused these injuries in at least $70.5 \%$ of the affected animals. In addition, remains of nylon gillnets were seen in five $S$. guianensis from Sepetiba Bay (Figure $6 b$ ) and two from northern RJ (Fragoso, 2001; Ramos et al., 2001; Table 5). In a number of species, incisive wounds and scars possibly inflicted by propellers are currently under study, in an effort to identify confirmed cases (see Van Waerebeek et al., 2007, this volume). A healing, large shark bite was observed in at least one free-ranging S. guianensis from Sepetiba Bay (Figure 6c).

\section{Lesions of the skeleton}

Lesions of the skeleton were classified into four categories (Table 6). Prevalence of osteopathology ranged from a low $5.4 \%$ in Peruvian P. spinipinnis up to a high $69.1 \%$ in Peruvian offshore T. truncatus.

\section{$>$ Malformations}

BRAZIL. Among 53 S. guianensis collected in 1987-1998 in northern RJ, congenital malformations were detected in $7.6 \%$ of the skulls and $9.4 \%$ of axial skeletons (Table 6). They affected the maxillaries, premaxillaries, mandibles, occipital, cervical and thoracic vertebrae, sternum and ribs. Three mature females showed multiple malformations of the whole skeleton. Malformations of the axial skeleton characterized by an incomplete closure of the vertebral arch of the seventh cervical vertebra and sometimes associated with the presence of cervical ribs, were observed in $48.4 \%$ of 31 S. guianensis gathered in the same region in 2001-2006 (Figure 7). Most (66.7\%) affected specimens were immature. The spinal processes of some thoracic and caudal vertebrae were abnormally curved in an immature female inshore T. truncatus from northern RJ. 


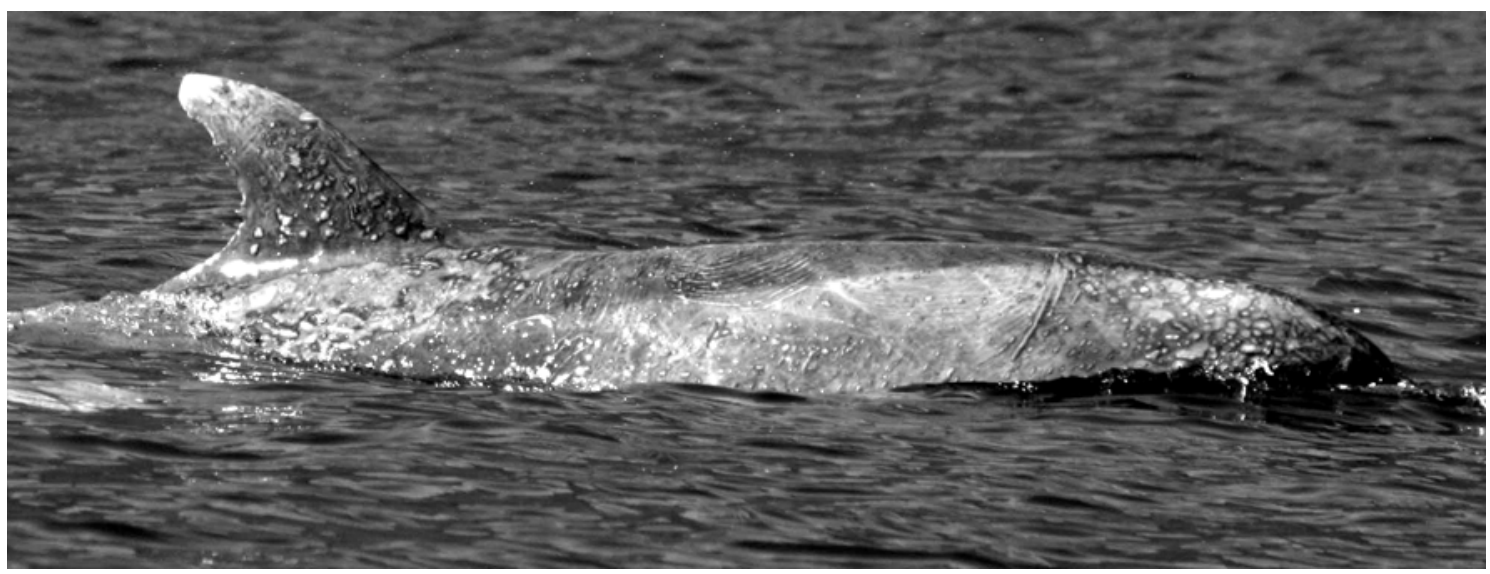

Figure 5. Vesicles on the skin of a female Tursiops truncatus (TTR-143) from southern Chile.

Table 4. Prevalence of externally visible traumata, cutaneous woundsa, large or deep scars and abscesses in small cetaceans from South America, with an indication (\%) of possible human-related origin.

\begin{tabular}{|c|c|c|c|c|c|c|c|c|c|c|}
\hline \multirow{2}{*}{$\begin{array}{l}\text { COUNTRY \& } \\
\text { SPECIES } \\
\end{array}$} & \multirow[b]{2}{*}{ REGION } & \multirow{2}{*}{$\begin{array}{c}\text { SAMPLING } \\
\text { PERIOD } \\
\end{array}$} & \multicolumn{4}{|c|}{$\begin{array}{l}\text { CUTANEOUS WOUNDS, } \\
\text { SCARS AND ABSCESSES }\end{array}$} & \multicolumn{4}{|c|}{$\begin{array}{c}\text { TRAUMATA } \\
\text { (EXTERNALLY VISIBLE) }\end{array}$} \\
\hline & & & $\mathrm{N}$ & NPOS & PREV & $\mathrm{HR}$ & $\mathrm{N}$ & NPOS & PREV & $\mathrm{HR}$ \\
\hline \multicolumn{11}{|l|}{ Peru } \\
\hline Delphinus capensis & Central coast & 1990-1994 & 54 & 15 & $27.8 \%$ & $80 \%$ & 545 & 3 & $0.6 \%$ & $100 \%$ \\
\hline Lagenorhynchus obscurus & Central coast & 1993-1994 & 240 & 13 & $5.4 \%$ & $30.8 \%$ & 240 & 4 & $1.7 \%$ & $25 \%$ \\
\hline Phocoena spinipinnis & Central coast & 1991-1994 & 106 & 22 & $20.8 \%$ & $45.5 \%$ & 106 & 2 & $1.9 \%$ & $50 \%$ \\
\hline Tursiops truncatus, inshore & Central coast & 1985-1989 & 16 & 0 & $0 \%$ & - & 16 & 3 & $18.8 \%$ & $66.7 \%$ \\
\hline Tursiops truncatus, inshore & Paracas Bay & 2004-2006 & 70 & 1 & $1.4 \%$ & $0 \%$ & 70 & 3 & $4.3 \%$ & $66.7 \%$ \\
\hline Tursiops truncatus, offshore & Central coast & $1985-1990$ & 52 & 2 & $3.8 \%$ & $0 \%$ & 52 & 4 & $7.7 \%$ & $28.6 \%$ \\
\hline Tursiops truncatus, offshore & Central coast & 1993-1994 & 13 & 2 & $15.4 \%$ & $50 \%$ & 13 & 1 & $7.7 \%$ & $100 \%$ \\
\hline \multicolumn{11}{|l|}{ Chile } \\
\hline Lagenorhynchus australis & $\begin{array}{l}\text { Northern } \\
\text { Patagonia }\end{array}$ & 2003 & 45 & 1 & $2.2 \%$ & $100 \%$ & - & 45 & 0 & $0 \%$ \\
\hline \multicolumn{11}{|l|}{ Brazil } \\
\hline Sotalia guianensis & Sepetiba Bay & 2005-2007 & 168 & 8 & $4.8 \%$ & $87.5 \%$ & 168 & 10 & $6 \%$ & $80 \%$ \\
\hline \multicolumn{11}{|l|}{ Venezuela } \\
\hline Stenella frontalis & Central coast & 2005 & 200 & 1 & $0.5 \%$ & indet & 200 & 3 & $1.5 \%$ & $100 \%$ \\
\hline Stenella frontalis & Central coast & $1996-2000$ & ne & ne & ne & ne & $100-400$ & 1 & $0.25-1 \%$ & indet \\
\hline
\end{tabular}

$\mathrm{N}=$ number of specimens examined, Npos= number of positive, prev $=$ prevalence, $\mathrm{HR}=$ human related, ne $=$ not examined, indet $=$ indetermined; ${ }^{a}=$ not including harpoon wounds that caused death.

PERU. Congenital malformations of the skull were observed in L. obscurus, D. capensis and inshore $T$. truncatus but not in P. spinipinnis and offshore T. truncatus (Table 6). Severe malformations involved the cranium of a L. obscurus (Figure 8) and a D. capensis (Van Bressem et al., 2006b). In other dolphins lesions were benign (brachygnathia, prognathism, beak deviation) and likely did not interfere with feeding or other vital activities.
$>$ Fractures and other traumata

BRAZIL. Among 53 S. guianensis from northern RJ collected in 1987-1998, the following percentages showed fractures affecting the ribs $(20.8 \%)$, scapulae $(1.9 \%)$ and vertebrae (22.6\%) including cervical $(9.5 \%)$, thoracic (3.8\%), lumbar L6-L8 (15.1\%) and caudal (5.7\%) vertebrae. Among S. guianensis collected in the same region in 2001-2006, fractures of the hemi-arches of C7, T1 and T2 were observed in a mature specimen of unknown sex (3.2\%). 


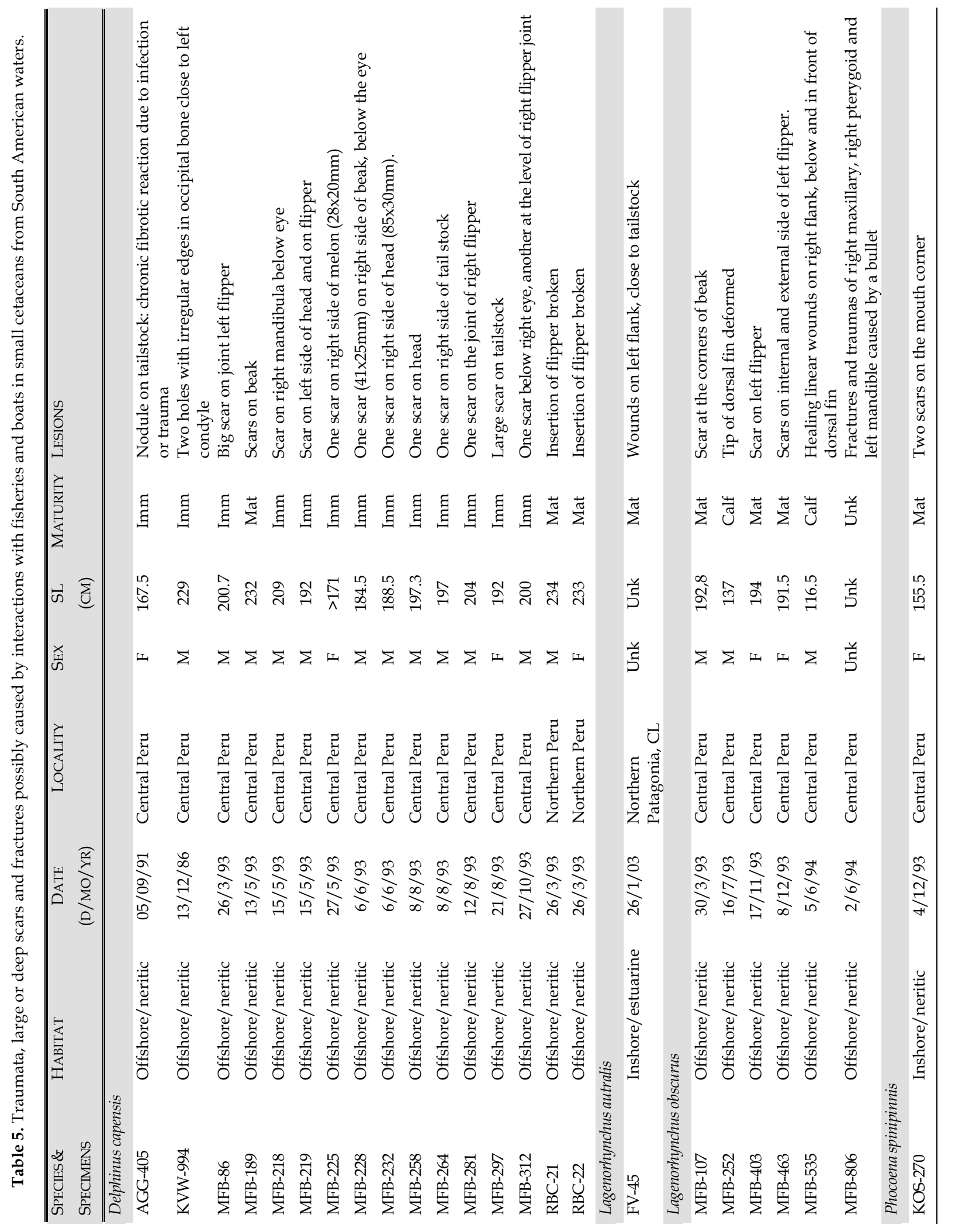




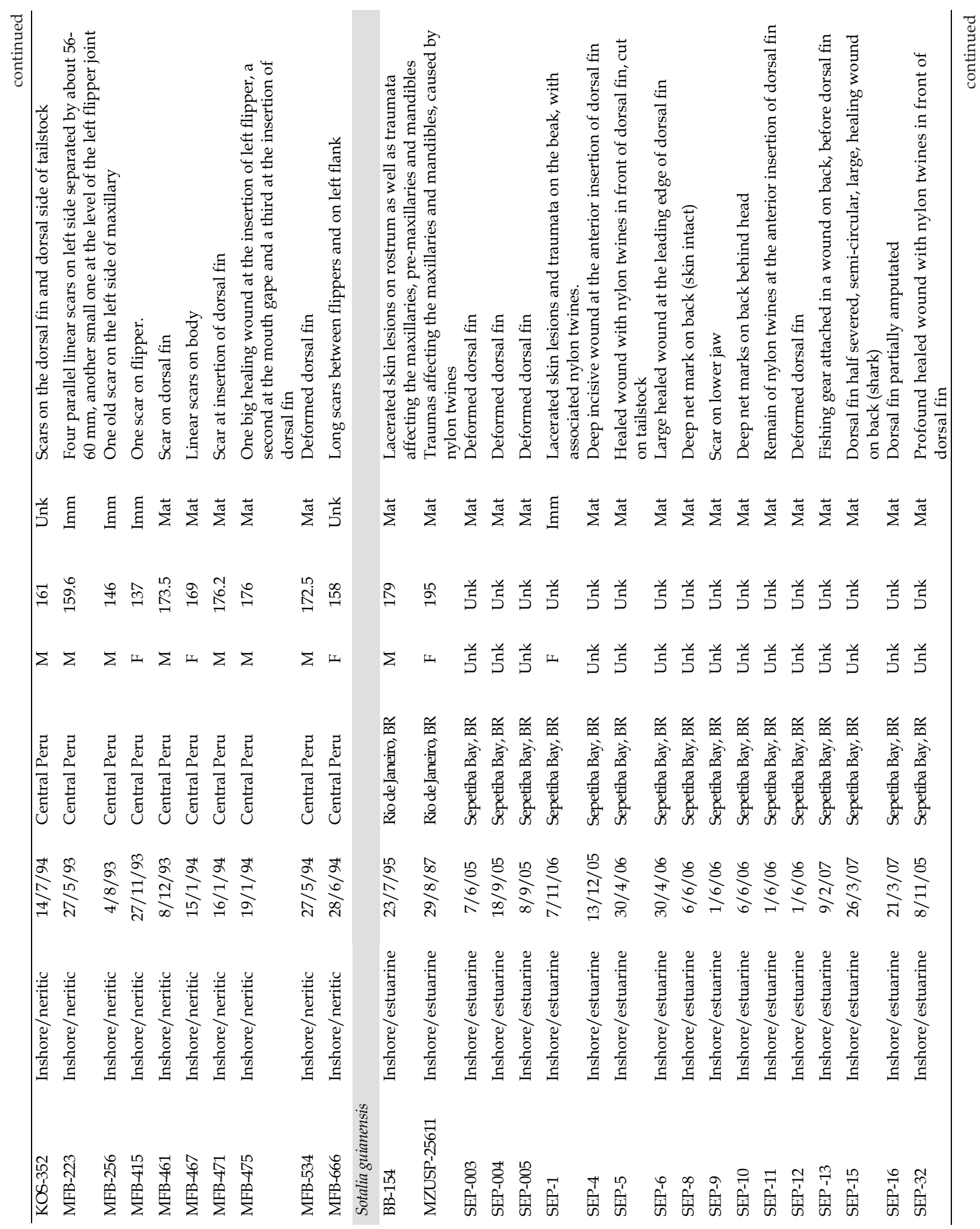




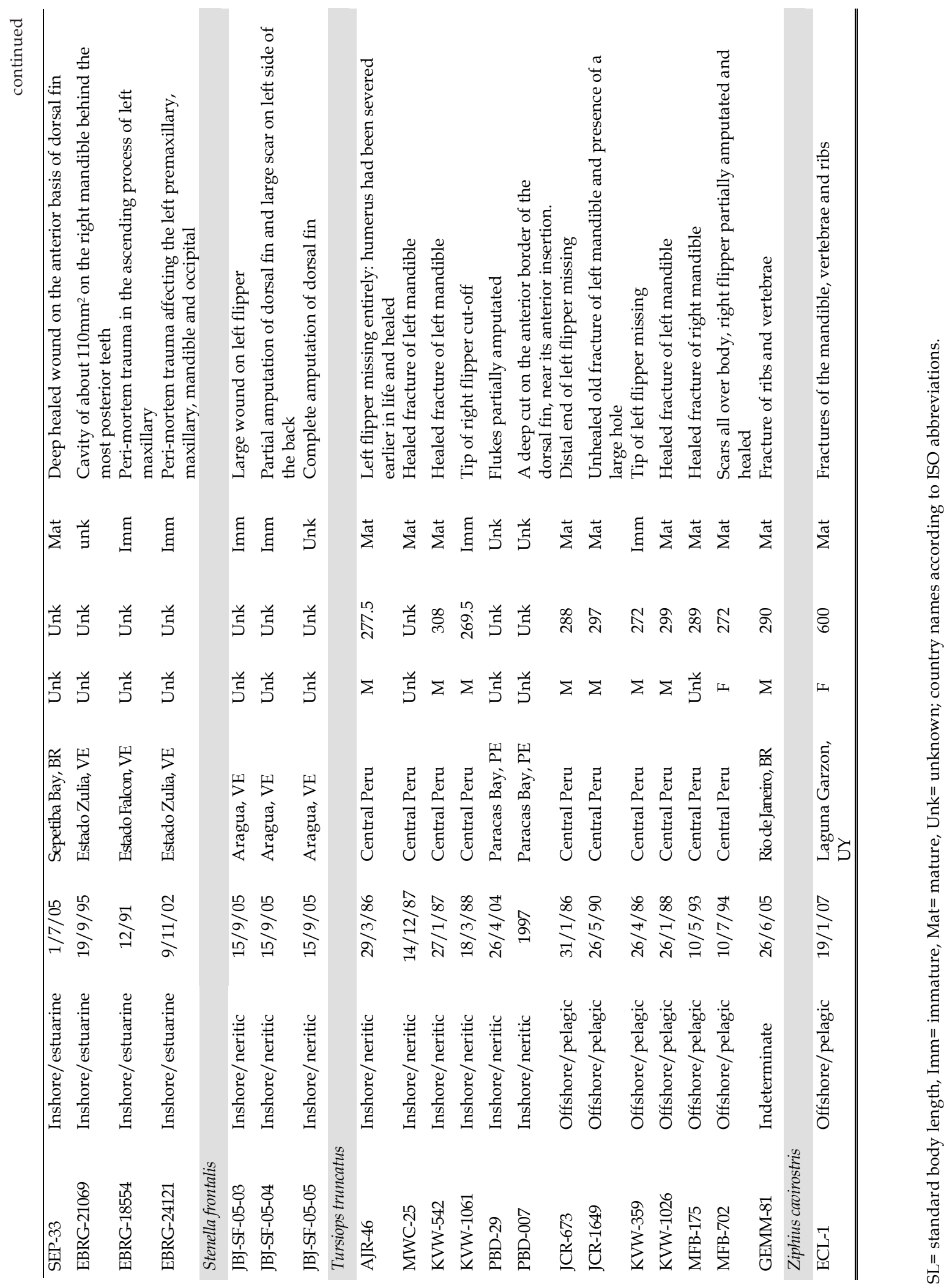




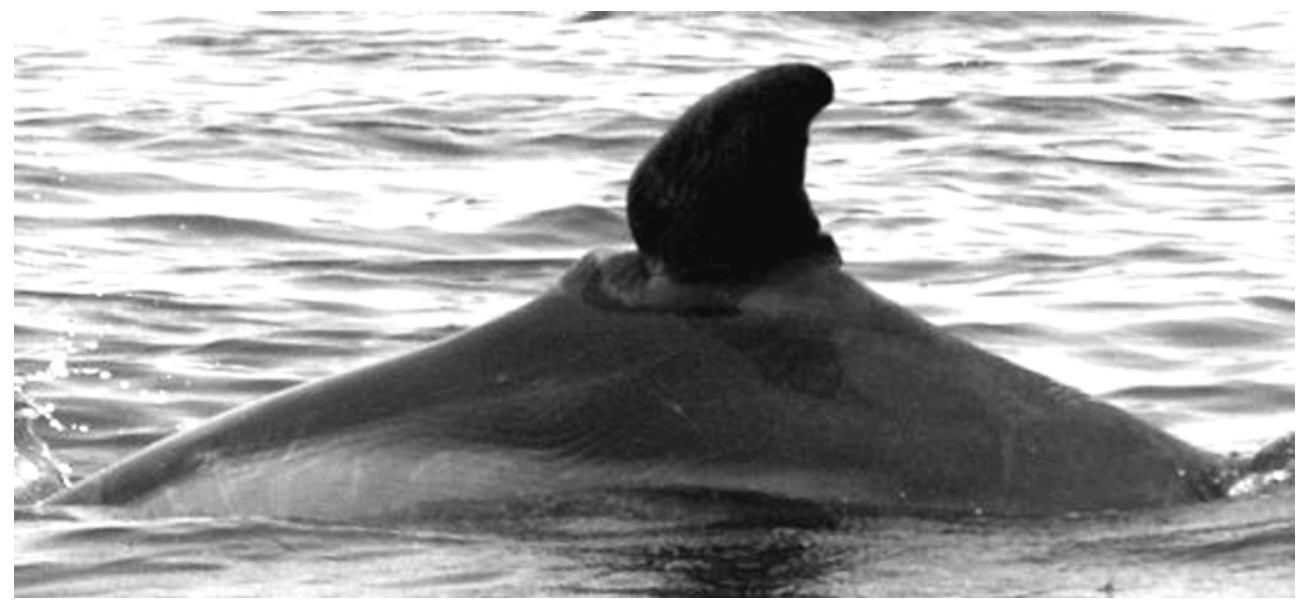

Figure 6a. Deep cut on the anterior insertion of the dorsal fin in an inshore Tursiops truncatus (PBD-007) from the Bay of Paracas (Peru).

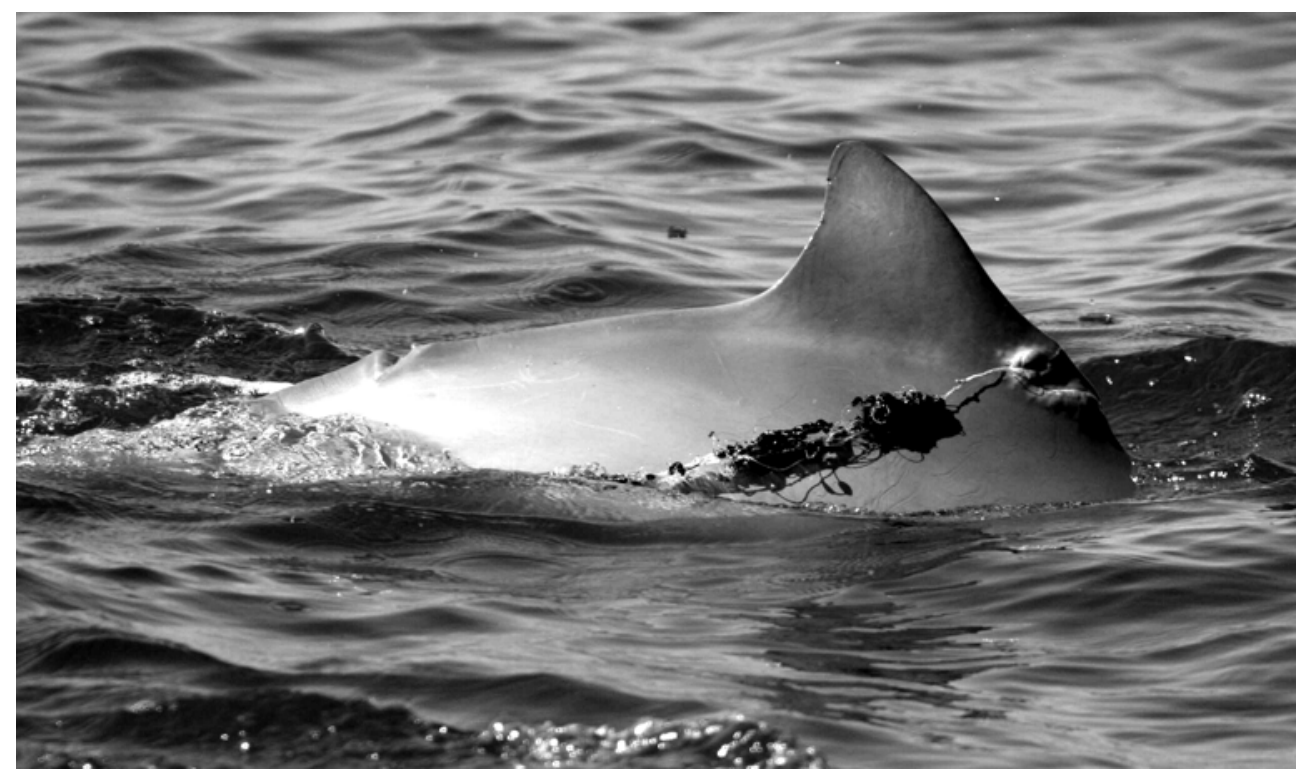

Figure 6b. Remains of a nylon twines encroached in a large scar on the anterior basis of the dorsal fin and healing lesion on the tailstock of an adult Sotalia guianensis (SEP-005) from Sepetiba Bay (Brazil).

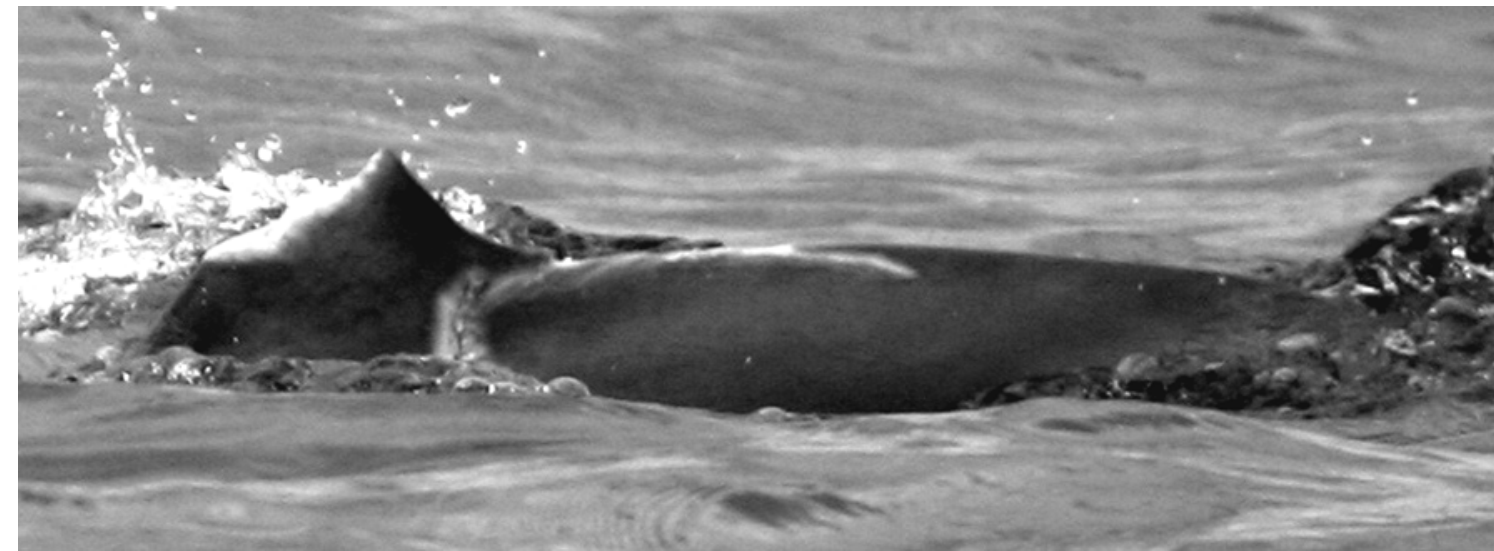

Figure 6c. Half-severed dorsal fin together with a large scar from a shark bite in a free-ranging Sotalia guianensis (SEP-015) from Sepetiba Bay (Brazil) 


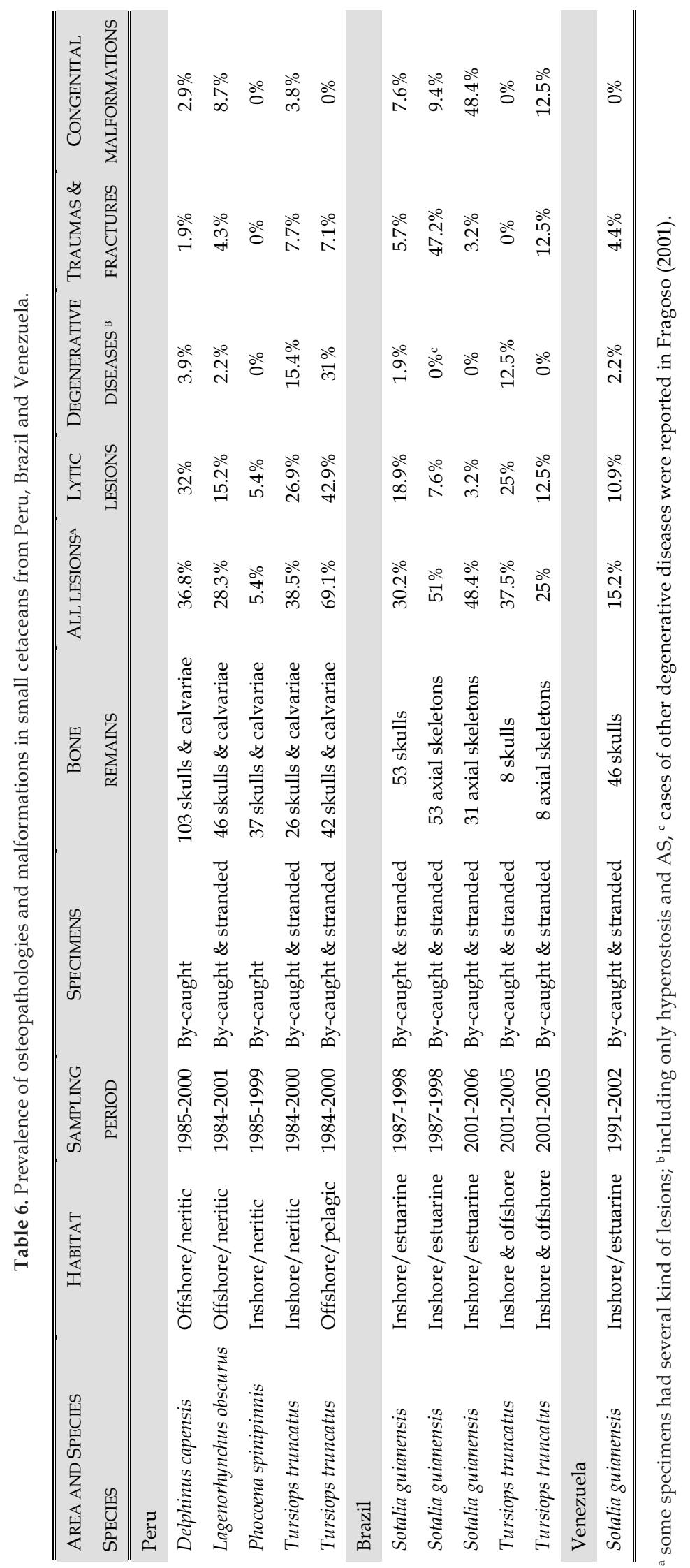

These injuries may have been inflicted by violent conspecific or interspecific interactions (see e.g. Jepson and Baker, 1998), fishery interactions or resulted from congenital defects and functional stress (Fragoso, 2001; Laeta et al., 2006 ${ }^{20}$ ). In the 1987-1998 sample, lesions of the skull associated with remains of fishing gear were seen in two mature dolphins. Finally, the palatine of a juvenile male was perforated as from a sharp fish spine or bone. An adult male T. truncatus (GEMM-081) livestranded in RJ in 2005 showed healed and nonhealed fractures of several ribs (both left and right) and of the neural process of the fourth and fifth thoracic vertebrae. These traumata were also likely caused by conspecific, interspecific or fishery interactions.

Peru. Among four species, prevalence of fractures and traumas in by-caught specimens varied from $0 \%$ in $P$. spinipinnis to $7.7 \%$ in inshore T. truncatus (Table 6). Healed or nonhealed fractures were encountered in the mandibles of one L. obscurus, one D. capensis, two inshore T. truncatus and three offshore $T$. truncatus, all adults (Figure $9 a$ ), either from the impact of fishing gear or from violent conspecific or interspecific interactions. In two other cases the injuries were definitely anthropogenic. A L. obscurus was shot in the head and the impact of the bullet was seen in the right maxillary, right pterygoid and left mandible. Two holes (diameters 15 and $5 \mathrm{~mm}$ ) with irregular edges, likely inflicted by an unidentified piercing object, perforated the occipital bone close to the left condyle in a mature male D. capensis (Van Bressem et al., $2006 b$ ). The non-healed fracture in the mandible of a mature T. truncatus may also have had an anthropogenic origin (Figure $9 a$ ).

Venezuela. Perimortem traumata, possibly inflicted by a piercing or smashing object were observed in the skull of two immature S. guianensis found in Falcón (1991) and Zulia (2002) (Tables 5 and 6)

URUGUAY. A cranially mature female Cuvier's beaked whale ( $Z$. cavirostris) stranded in Laguna Garzon at an indeterminate date during 1998-2000 had healed fractures in the two posterior lumbar vertebrae, two anterior caudal vertebrae, and healing complete fractures in three ribs and the right mandible. Such findings of multiple fractures would be consistent with a collision with a large vessel. A cranially mature $P$. crassidens found in Laguna Garzon in the same period had fractures in two ribs. 


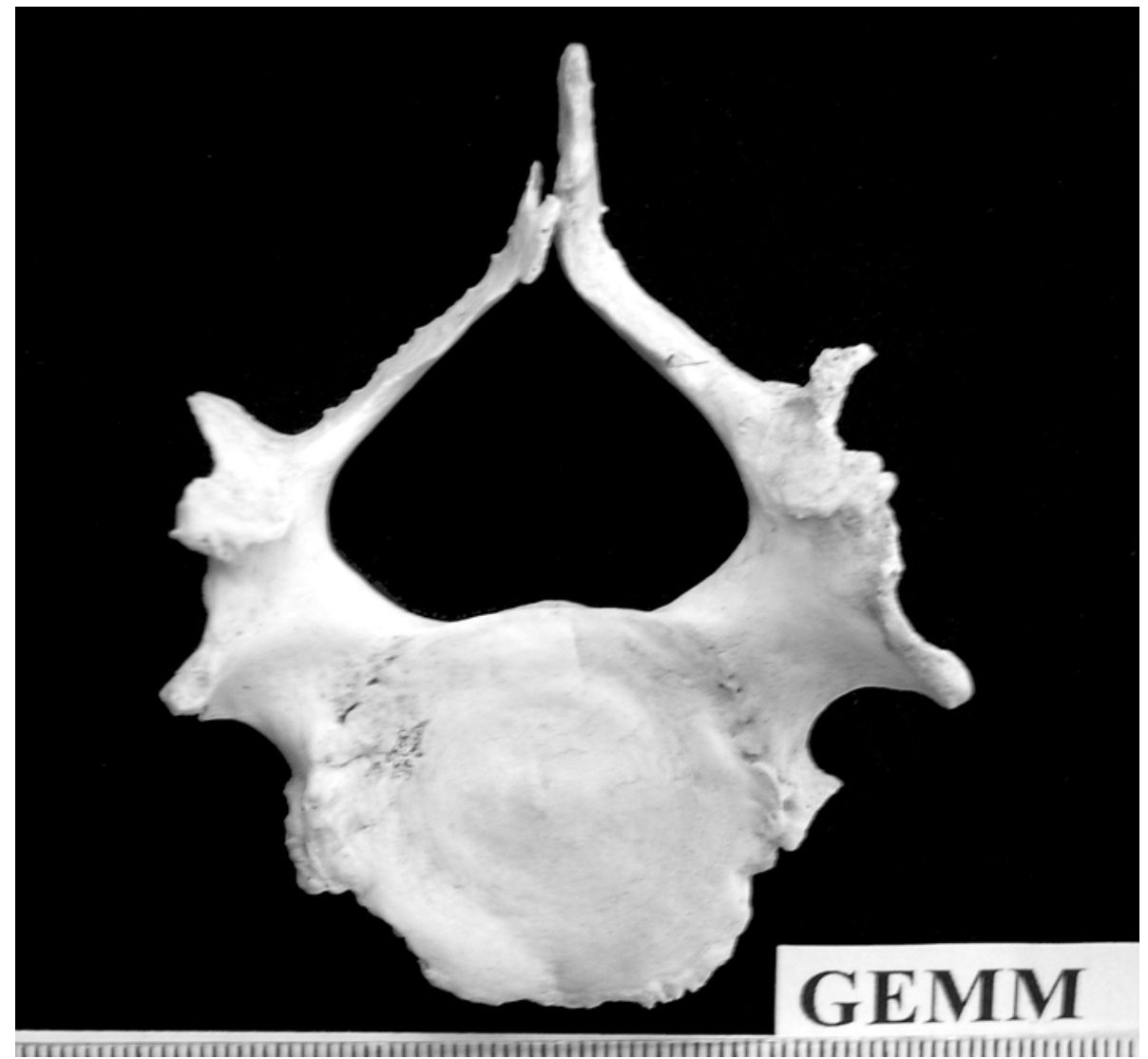

Figure 7. Congenital malformations in the seventh cervical vertebra of a Sotalia guianensis (GEMM-068) from northern Brazil.

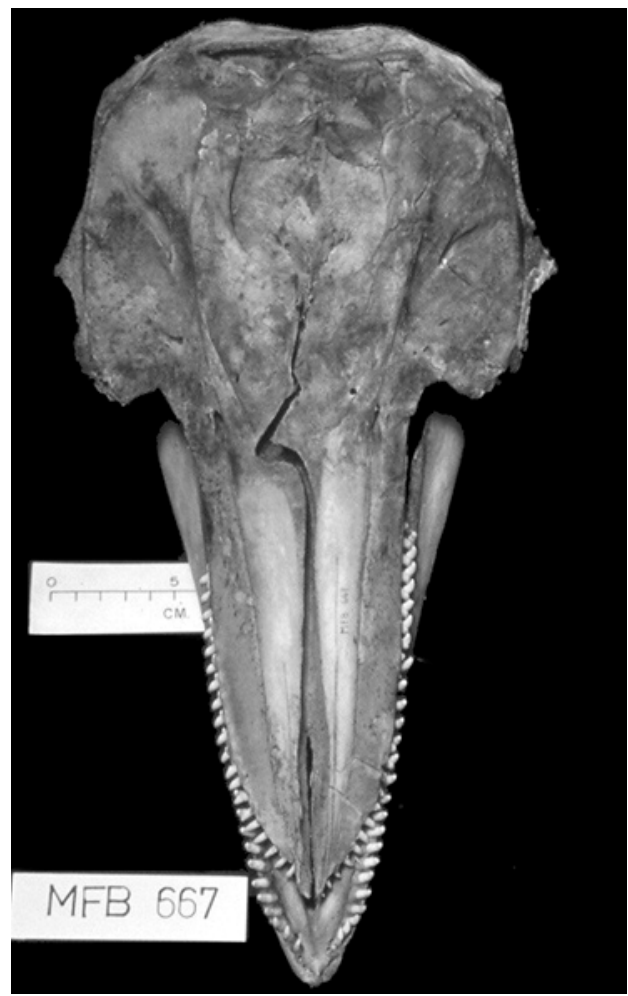

Figure 8. Complete skull malformation in an adult Lagenorhynchus obscurus (MFB-667) (Peru). 
$>$ Lytic lesions

Osteomyelitis AND Osteolysis. Osteomyelitis is characterized by non-specific acute or chronic, localized or generalized, bone infection accompanied by bone destruction or dissolution (osteolysis) and new bone formation. Prevalence of such lesions is given in Table 7. In S. guianensis from Brazil osteomyelitis and osteolysis were diagnosed in the stylohyoid (one case), the occipital condyles and atlasaxis block (one case), the scapulae (two cases) and in the lumbar and caudal vertebrae (two cases). In $S$. guianensis from Venezuela, osteomyelitis and osteolysis were detected only in the maxillaries and mandibles (Figure 9b). In Peruvian cetaceans, they mostly affected the mandibles, maxillaries and premaxillaries (Figure 10a). In one D. capensis, osteomyelitis also affected the pterygoid and palatine. An offshore T. truncatus presented extensive osteolysis in the left mandibular ramus (Figure 9a). In both dolphins, the osteolytic lesions may have been caused by a trauma. Some osteolysis was observed in both scapulae of a Z. cavirostris (Figure 10b) stranded in Laguna Garzon (Uruguay) and in an immature, female inshore T. truncatus found along the coast of RJ in 2001. Possible osteomyelitis was reported in a caudal vertebra of a P. crassidens stranded in Laguna Garzon that also suffered extensive hyperostosis and ankylosing spondylitis.

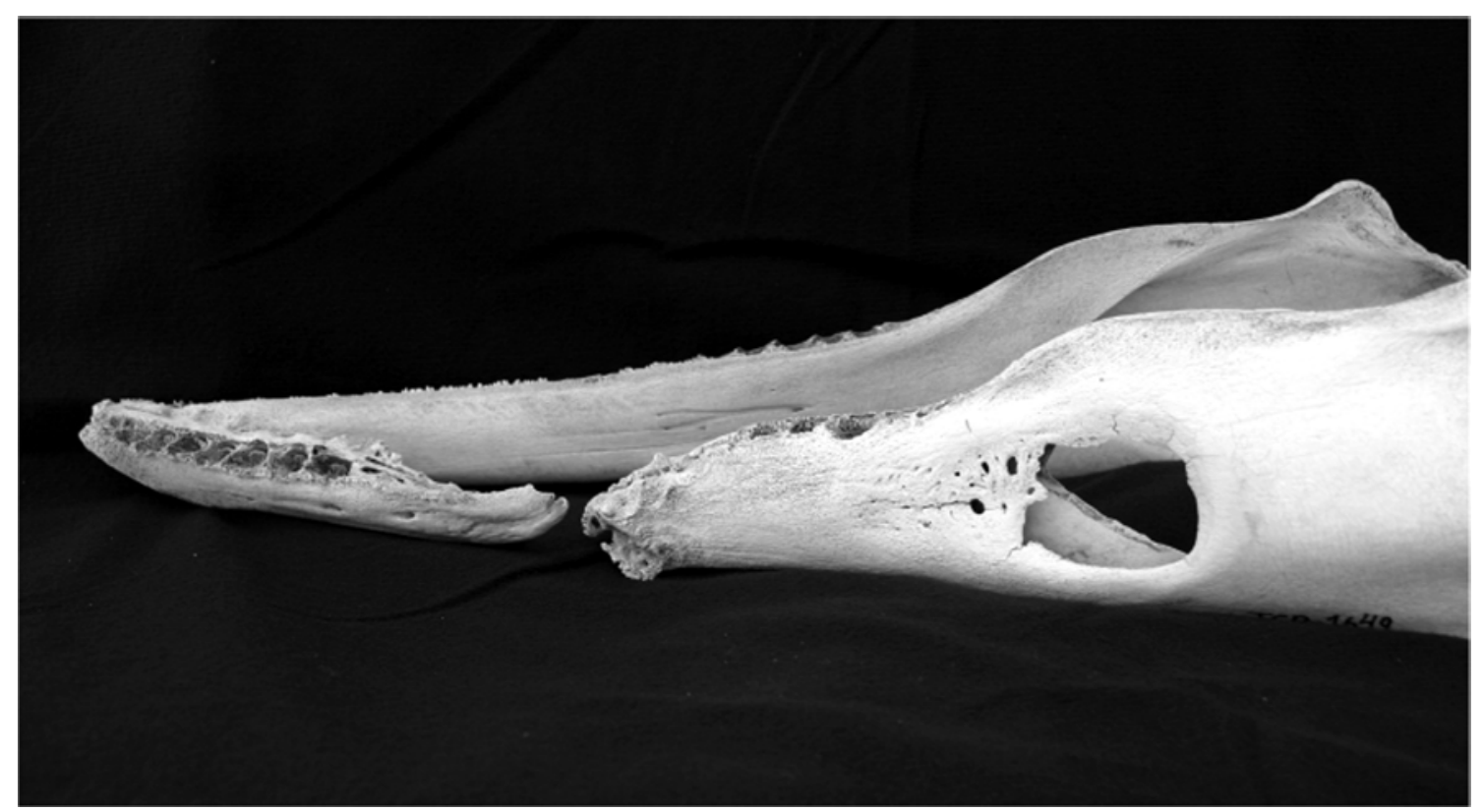

Figure 9a. Complete fracture of the left mandible together with a large, oval lytic lesion in an adult offshore Tursiops truncatus (JCR-1649) (Peru).

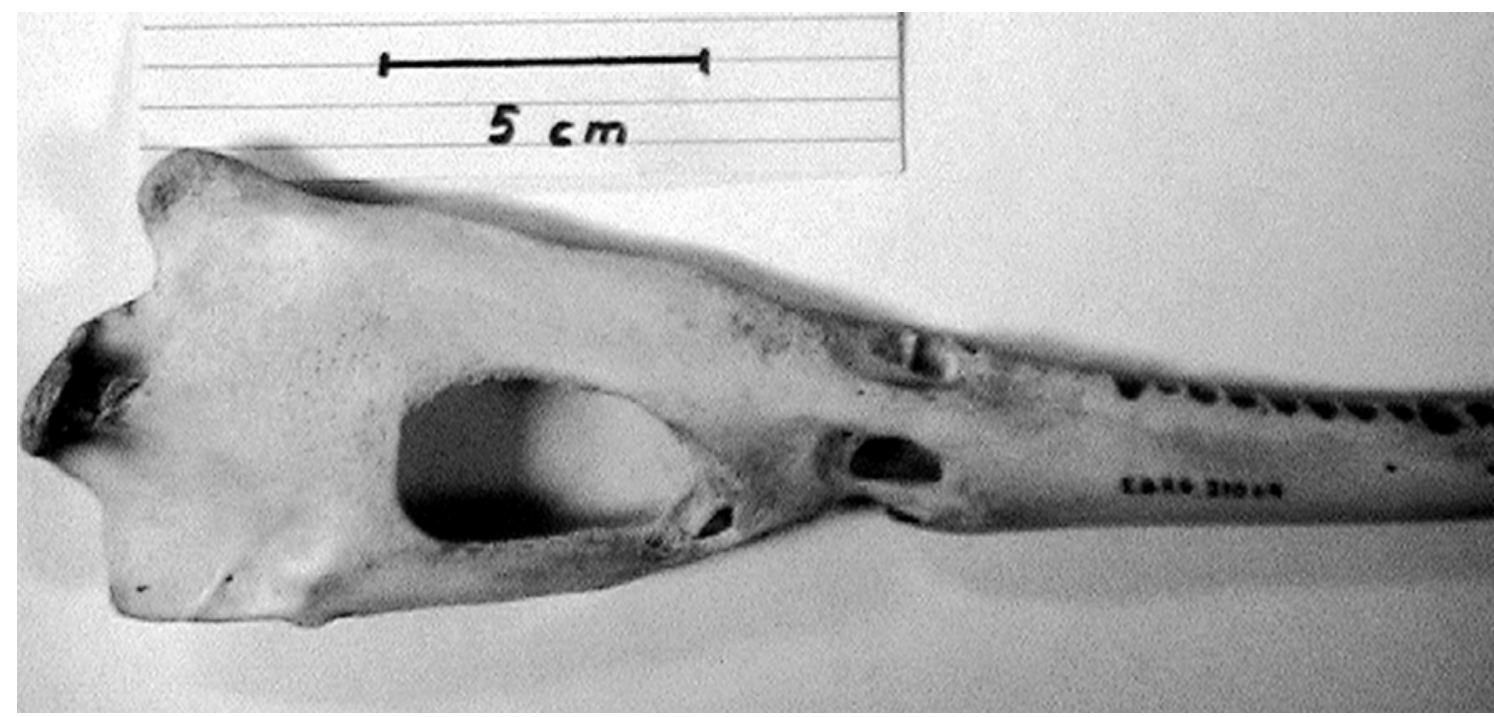

Figure 9b. Osteolysis and osteomyelitis on the right mandible of a Sotalia guianensis (EBRG-21069) from Venezuela. 
Table 7. Prevalence of lytic lesions in small odontocetes from Peru, Brazil and Venezuela.

\begin{tabular}{|c|c|c|c|c|c|c|c|c|}
\hline \multirow[t]{2}{*}{ AREA AND SPECIES } & \multirow[t]{2}{*}{ НABITAT } & SAMPLING & \multicolumn{2}{|l|}{ BONE } & \multicolumn{3}{|c|}{ LYTIC LESIONS } & \multirow[b]{2}{*}{ PLD } \\
\hline & & PERIOD & REMAINS & $\mathrm{N}$ & $\begin{array}{c}\text { CRASSICAUDA } \\
\text { SPP. }\end{array}$ & OSTEOMYELITIS & OSTEOLYSIS & \\
\hline \multicolumn{9}{|l|}{ Peru } \\
\hline Delphinus capensis & Offshore/neritic & $1985-2000$ & Skulls & 103 & $26.5 \%^{a}$ & $1.9 \%$ & $4.9 \%$ & $1 \%$ \\
\hline $\begin{array}{l}\text { Lagenorhynchus } \\
\text { obscurus }\end{array}$ & Offshore/neritic & 1984-2001 & Skulls & 46 & $4.4 \%$ & $0 \%$ & $2.1 \%$ & $8.7 \%$ \\
\hline Phocoena spinipinnis & Inshore/neritic & 1985-1999 & Skulls & 37 & $0 \%$ & $2.7 \%$ & $5.4 \%$ & $2.7 \%$ \\
\hline Tursiops truncatus & Inshore/neritic & $1984-2000$ & Skulls & 26 & $7.7 \%$ & $7.7 \%$ & $7.7 \%$ & $15.4 \%$ \\
\hline Tursiops truncatus & Offshore/pelagic & $1984-2000$ & Skulls & 42 & $26.2 \%$ & $4.8 \%$ & $9.5 \%$ & $16.7 \%^{\mathrm{b}}$ \\
\hline \multicolumn{9}{|l|}{ Brazil } \\
\hline Sotalia guianensis & Inshore/estuarine & 1987-1998 & Skulls & 53 & $1.9 \%^{c}$ & $1.9 \%$ & $0 \%$ & $15.1 \%$ \\
\hline Sotalia guianensis & Inshore/estuarine & 1987-1998 & $\begin{array}{c}\text { Axial } \\
\text { skeleton }\end{array}$ & 53 & - & $7.6 \%$ & $0 \%$ & - \\
\hline Sotalia guianensis & Inshore/estuarine & 2001-2006 & $\begin{array}{c}\text { Axial } \\
\text { skeletons }\end{array}$ & 31 & - & $3.2 \%$ & $0 \%$ & - \\
\hline Tursiops truncatus & Inshore \& offshore & 2001-2005 & Skulls & 8 & $25 \%$ & $0 \%$ & $0 \%$ & indet. \\
\hline Tursiops truncatus & Inshore \& offshore & 2001-2005 & Skeletons & 8 & - & $12.5 \%$ & $12.5 \%$ & - \\
\hline \multicolumn{9}{|l|}{ Venezuela } \\
\hline Sotalia guianensis & Inshore/estuarine & 1991-2003 & Skulls & 46 & $0 \%$ & $2.2 \%$ & $6.5 \%$ & $10.9 \%$ \\
\hline
\end{tabular}

$\mathrm{N}=$ total number of specimens, $\mathrm{PLD}=$ periodontal lytic disease; indet. $=$ indeterminate, ${ }^{\mathrm{a}} \mathrm{N}=98{ }^{\mathrm{b}}{ }^{\mathrm{b}}$ this percentage may be an underestimate; c possible Crassicauda spp. infestation in one Sotalia guianensis.

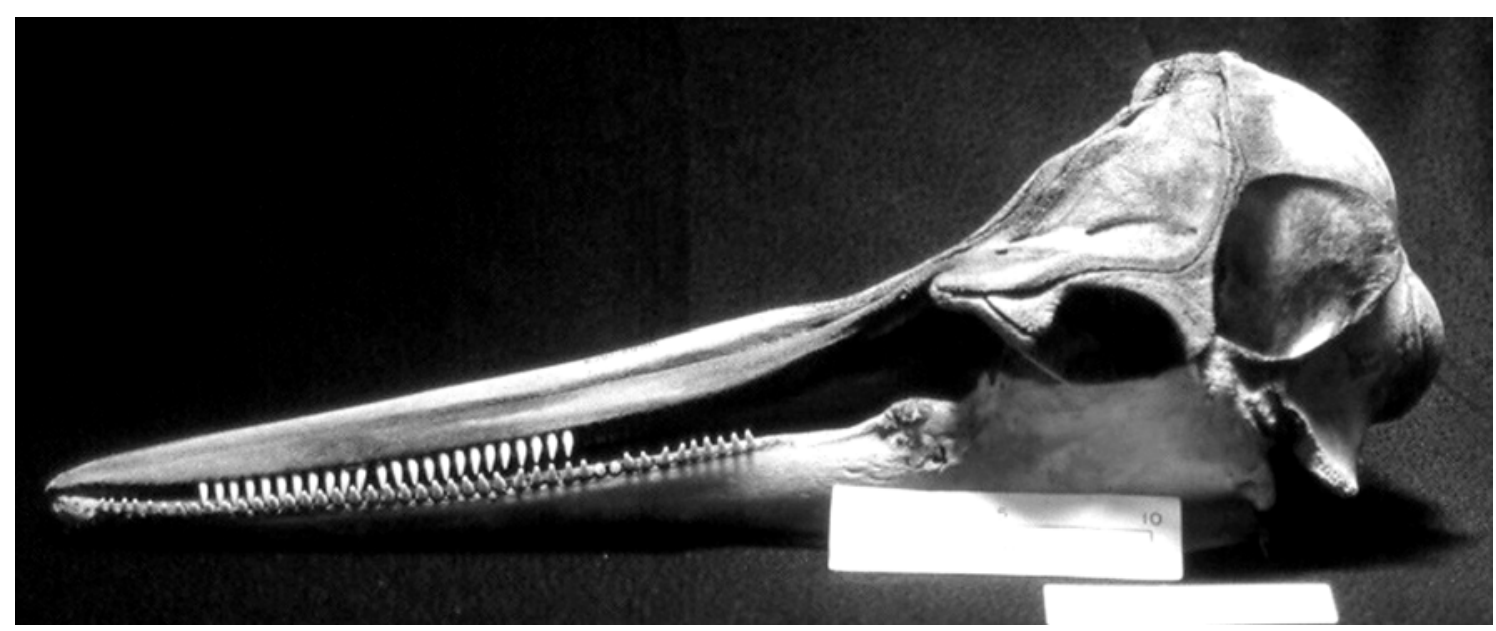

Figure 10a. Osteomyelitis in the left mandible of a mature Delphinus capensis (KVW-2400) (Peru).

Periodontal Lysis. Periodontal lysis (Table 7), presumably caused by miscellaneous local infections in mature and immature odontocetes (Figure 11) represented from $6.1 \%$ (D. capensis, Peru) to $100 \%$ ( $P$. spinipinnis, Peru) of the cases of osteolysis and osteomyelitis observed in skulls from Peru, Brazil and Venezuela (Table 7).

Crassicaudiasis. Crassicaudiasis was detected in all species except in $P$. spinipinnis from Peru and $S$. guianensis from Venezuela (Figure 12; Table 7). Possible Crassicauda lesions were also seen in the pterygoids of a mature S. guianensis from northern RJ. The pterygoid bones were most frequently affected in all species except in L. obscurus where only the alisphenoid, basioccipital and frontal were damaged. Prevalence of Crassicauda spp. lesions varied significantly $\left(X^{2}=10,46, \mathrm{df}=1, \mathrm{P}=0.0012\right)$ according to the species and ecotypes, being higher in $D$. capensis and offshore T. truncatus from Peru (Table 7). 
Figure 10b. Osteolysis in the scapula of a mature Ziphius cavirostris (ZCAV-SN) (Uruguay).
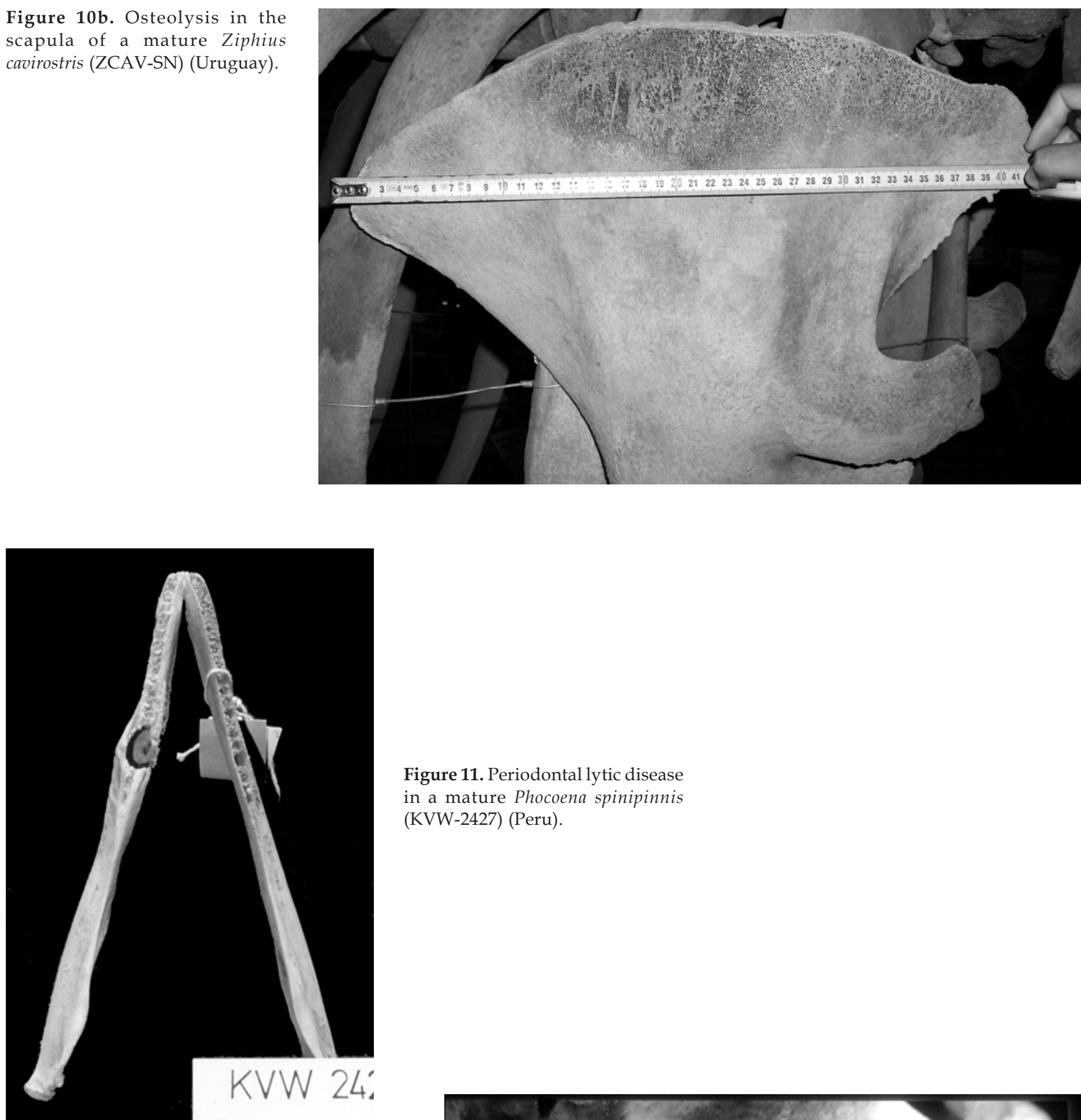

Figure 11. Periodontal lytic disease in a mature Phocoena spinipinnis (KVW-2427) (Peru).

Figure 12. Crassicauda spp. lesions in the skull of an immature offshore Tursiops truncatus (DMI-186) (Peru).

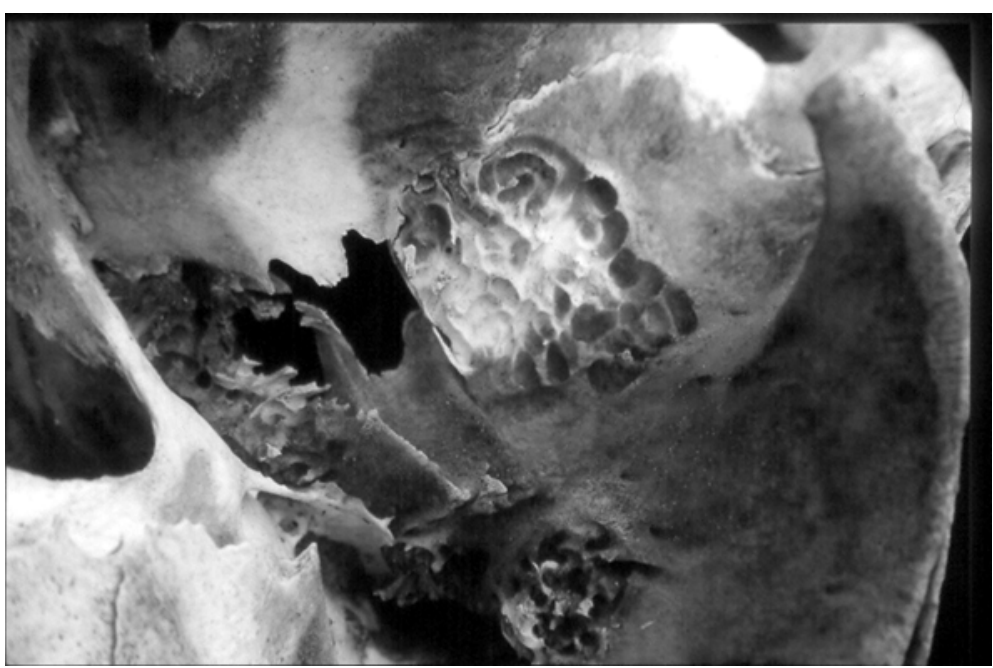


In $D$. capensis, prevalence did not vary significantly (Fisher's; $\mathrm{P}=0.8)$ between cranially adult females $(25 \%$, $\mathrm{n}=8$ ) and males $(19.4 \%, \mathrm{n}=31)$, allowing pooling of sexes. Prevalence of Crassicauda cranial bone damage was similar $\left(X^{2}=0.177\right.$, df $\left.=1, \mathrm{p}=0.67\right)$ in cranially immature $(22.7 \%, \mathrm{n}=22)$ and adult $(27.3 \%, \mathrm{n}=66)$ dolphins (Van Bressem et al., 2006b). The same may be true in offshore T. truncatus but sub-samples were too small to verify this hypothesis (Table 8).

\section{$>$ Degenerative bone diseases}

Degenerative bone diseases including hyperostosis and ankylosing spondylitis were seen in all species examined with the exception of $P$. spinipinnis. They were especially frequent $(31 \%)$ in offshore T. truncatus from Peruvian waters (Table 6).

HYPEROSTOSIs. Hyperostosis, a condition characterized by diffuse or localised bone overgrowth, sometimes concurrent with bone rarefaction, was diagnosed in skulls from inshore and offshore T. truncatus (Figure 13a), L. obscurus and D. capensis from Peru as well as in the skull of an inshore T. truncatus from northern RJ and on the vertebrae of a $P$. crassidens from Uruguay. In Peruvian T. truncatus, this condition always affected the occipital bone and less frequently the nasals, maxillaries and frontal bone. Hyperostosis was benign or severe, affecting the whole skull. Prevalence of this condition in four sub-samples of offshore T. truncatus is given in Table 8 . In these dolphins, prevalence of hyperostosis seemed to be higher in mature males than in immature males and mature females. However, significance could not be statistically tested due to small sample size. Hyperostosis occurred in three immature and one mature inshore T. truncatus of unknown sex.

Table 8. Prevalence of Crassicauda spp., hyperostosis and ankylosing spondylitis in four sub-samples of offshore bottlenose dolphins from Peru.

\begin{tabular}{|c|c|c|c|c|c|c|c|c|c|c|}
\hline & & \multirow[b]{2}{*}{$\mathrm{N}$} & \multicolumn{2}{|c|}{$\begin{array}{l}\text { CRASSICAUDA SPP. } \\
\text { LESIONS }\end{array}$} & \multicolumn{3}{|c|}{ HYPEROSTOSIS } & \multicolumn{3}{|c|}{$\begin{array}{l}\text { ANKYLOSING } \\
\text { SPONDYLITIS }\end{array}$} \\
\hline & & & NPOS & PREV & $\mathrm{N}$ & NPOS & PREV & $\mathrm{N}$ & NPOS & PREV \\
\hline \multirow[t]{2}{*}{$\sigma^{1}$} & Immature & 5 & 2 & $40 \%$ & 5 & 1 & $20 \%$ & 5 & 1 & $20 \%$ \\
\hline & Mature & 12 & 4 & $33.3 \%$ & 12 & 8 & $66.7 \%$ & 12 & 2 & $16.7 \%$ \\
\hline \multirow[t]{2}{*}{ ㅇ } & Immature & 5 & 1 & $20 \%$ & 5 & 1 & $20 \%$ & 5 & 0 & $0 \%$ \\
\hline & Mature & 4 & 0 & $0 \%$ & 4 & 1 & $25 \%$ & 4 & 1 & $25 \%$ \\
\hline
\end{tabular}

$\mathrm{N}=$ total number of specimens; Npos = number of positive; Prev = prevalence.

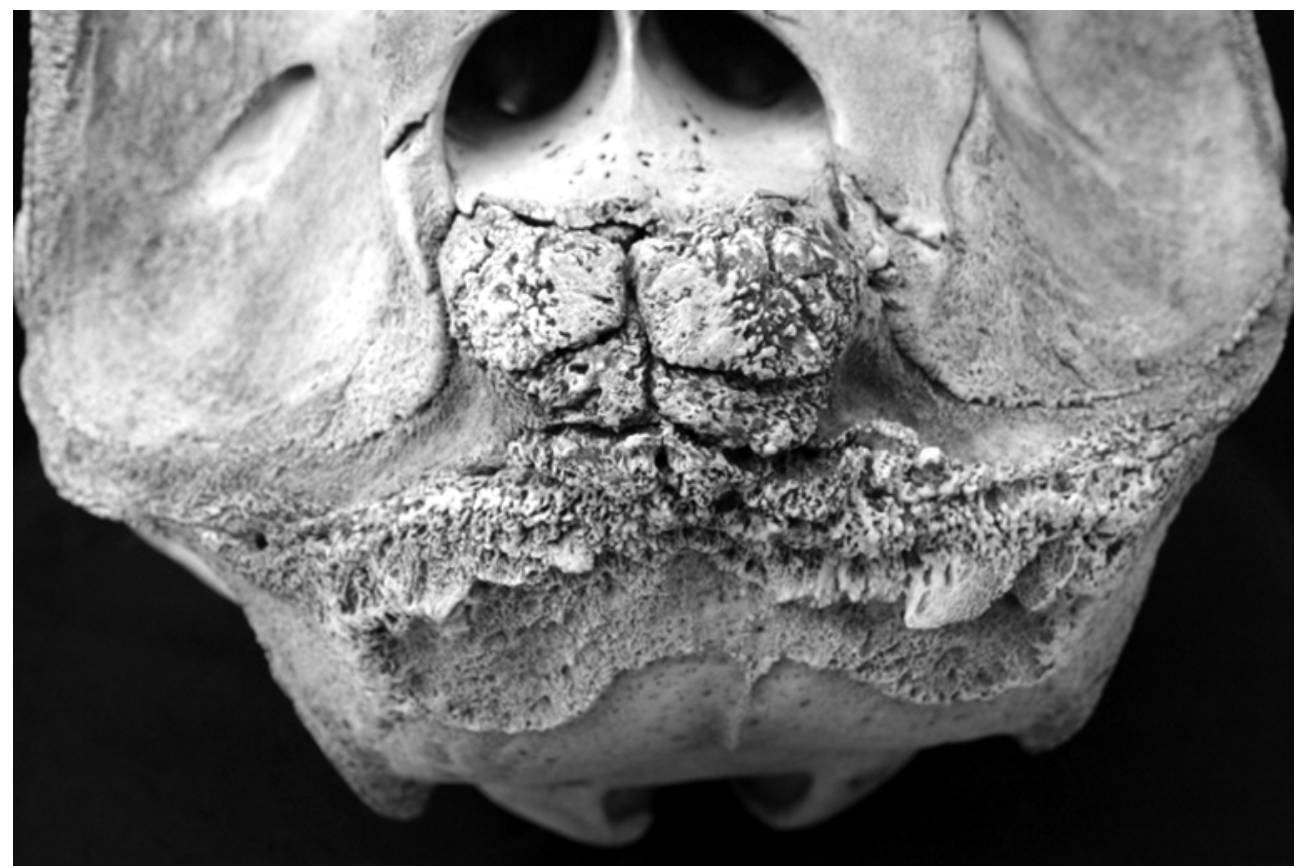

Figure 13a. Hyperostosis in a mature offshore Tursiops truncatus (JCR-1649) (Peru). 
ANKYLOSING SPONDYLITIS. Ankylosing spondylitis (AS) is a syndrome including new bone formation, loss of bone density and often resulting in the fusion of two or more vertebrae or the atlas ankylosing with the occipital bone, as well as other abnormal ankylosing processes (Sweeny et al., 2005). It was encountered in both T. truncatus ecotypes from Peruvian waters (Figure 13b) with prevalences of $3.9 \%$ and $9.5 \%$ in, respectively, 26 inshore and 42 offshore dolphins. All affected specimens also suffered hyperostosis. The only inshore bottlenose dolphin with AS was an immature $(176 \mathrm{~cm})$ individual of unknown sex. All its cervical vertebrae were ankylosed into one block and the atlas had started to fuse with the occipital. Possible AS was also observed in the caudal vertebrae of an immature $D$. delphis and the lumbar vertebrae of a mature T. truncatus stranded in the northern Gulf of Guayaquil (Ecuador) in 1998-1999 as well as in three caudal vertebrae of a $P$. crassidens from Uruguay.

\section{Discussion}

In this paper we documented and reviewed skin and skeletal diseases, congenital malformations and externally visible traumata, many apparently due to encounters with fishing gear and boats, in small cetaceans from SA waters.

Tattoo skin disease is caused by poxviruses that belong to a recently discovered genus of Chordopoxvirinae, but which have a common, most immediate ancestor with terrestrial poxviruses of the genus Orthopoxvirus (Flom and Houk, 1979; Geraci et al., 1979; Bracht et al., 2006). These viruses are thought to induce humoral immunity that may protect calves from the disease via colostrum ingestion (Smith et al., 1983; Van Bressem and Van Waerebeek, 1996). TSD was known only in odontocetes until 2006 when it was first reported from a bowhead whale (Balaena mysticetus) (Bracht et al., 2006). Here we report for the first time on the presence of TSD in D. delphis from Ecuador, $P$. spininnipis, T. truncatus and C. eutropia from Chile, C. commersonii from Argentina and S. guianensis from Brazil, thus extending the geographic area and the number of species susceptible to this disease. It is the first time that TSD is encountered in the SW Atlantic. With the exception of Peruvian dolphins and porpoises, the epizootiological status of TSD in SA small cetaceans is unknown and should be explored further. Though cetacean poxviruses apparently do not cause high mortality when endemic (Van Bressem et al.,1999), they could represent a significant threat to naive populations.

The appearance of velvety, sometimes ulcerative, skin marks as well as of large, rounded lesions in dolphins from Peru, Chile, Argentina and Brazil, we suggest, may be related to poor water quality. The bay of Paracas is heavily contaminated by organic material (phosphorus and organic nitrogen) released by fish-meal factories and surrounding towns, resulting in severe water eutrophication (PNUMA/CONAM, 2006). The factories also release caustic soda used to clean the machines (CPPS, 1998). In addition, ballast water from the numerous cargo ships transporting gas in the bay as a consequence of the CAMISEA project may introduce alien micro-organisms that could significantly harm ecosystems (Ruiz et al., 2000; PNUMA/CONAM, 2006; Drake et al., 2007). Chile's southern fjords are home to large numbers of salmon fish farms that continue to expand, heavily use prophylactic antibiotics that select antibiotic resistance in pathogenic bacteria and release biological and chemical contaminants directly into the ocean (Moore and Wieting, 1999; Kemper et al., 2003; Cabello, 2004; 2006). Interestingly, skin lesions were also reported from an appreciable number of blue whales (Balaenoptera musculus) off the northwestern coast of Isla Grande de Chiloé (Brownell et al., 2007) and Chañaral Island (G. P. Sanino, unpublished data), Chile.

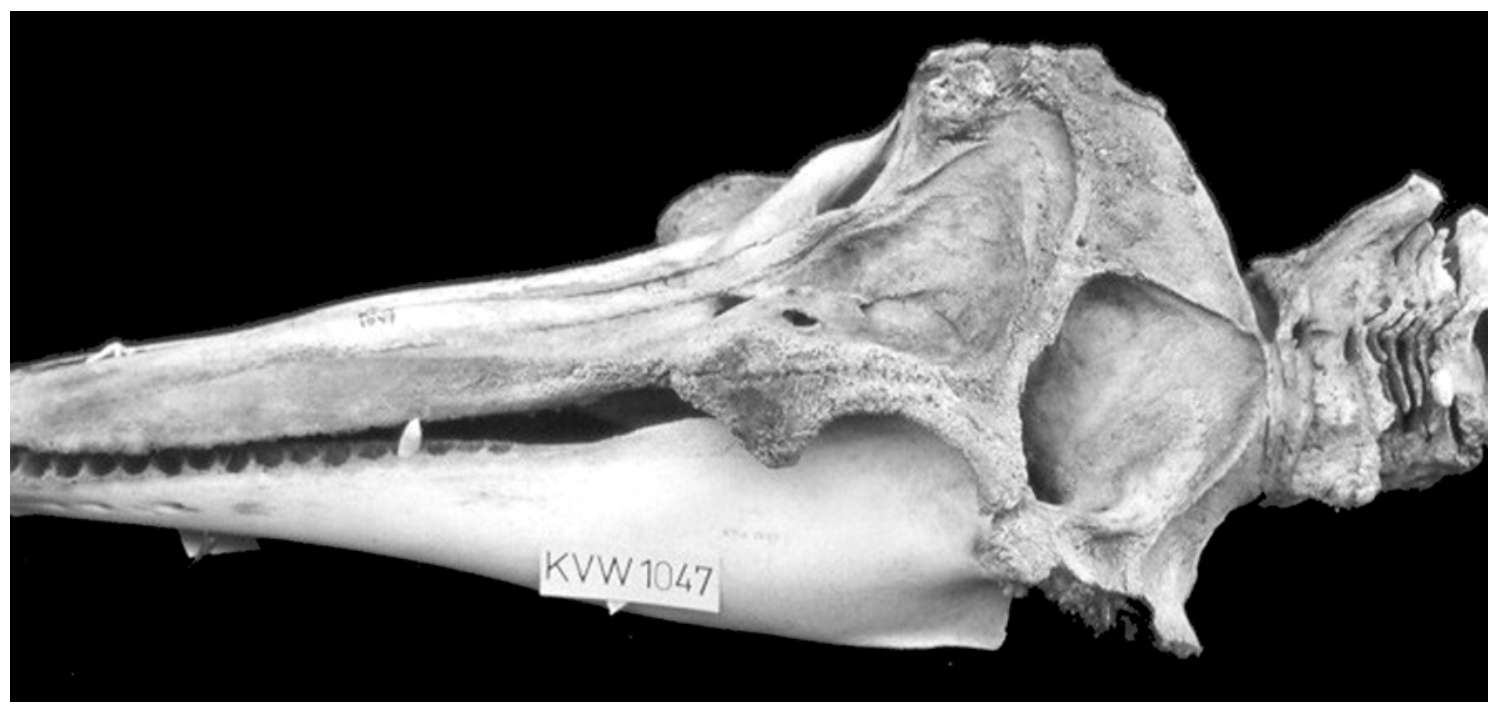

Figure 13b. Ankylosing spondylitis in a mature offshore Tursiops truncatus (KVW-1047) (Peru). All cervicals are fused into a single block, which is fused to the occipital. 
Sepetiba Bay in Brazil is home to two large ports and is characterized by chemical and organic pollution as well as water eutrophication (Copeland et al., 2003; Molisani et al., 2004).

Lobomycosis (or lacaziosis) is caused by a yeast-like organism known as Lacazia loboi (Taborda et al., 1999) (syn. Loboa loboi; Caldwell et al., 1975). It naturally affects humans and dolphins (T. truncatus and S. guianensis). In humans, it is a self-limited, chronic fungal infection of the skin endemic in rural regions in South and Central America. The natural reservoir of L. loboi is unknown but soil and vegetation seem to be likely sources of infection (Honda et al., 2007). Patients with lobomycosis may have immunoregulatory disturbances that could be responsible for the lack of pathogen containment (Vilani-Moreno et al., 2005; Honda et al., 2007). In T. truncatus from the southern part of the Indian River Lagoon, Florida, the disease was associated with an impaired immune function possibly caused by anthropogenic factors. Variation in salinity and water temperature may also play a role (Reif et al., 2006). During the present study lobomycosis-like disease was only seen in inshore populations of $T$. truncatus. Those from Colombia, Ecuador and southern Brazil (Santa Catarina) inhabited waters of low salinity and relatively high temperature situated close to mangroves and estuaries. All affected T. truncatus inhabited waters surrounding large ports and cities and, in the case of Guayaquil, also harbouring intense shrimp farming activities. Most of these waters are heavily polluted by chemicals and biological contaminants (CPPS, 2000; WHO/UNICEF/WSSCC, 2001; CVC, 2003; UNEP, 2006). It is quite likely that some of these pollutants affect the immune system of inshore dolphins as described for cetaceans elsewhere (Aguilar and Borrell, 1994; Jepson et al., 1999; Smyth et al., 2000). Ballast water from the numerous cargo ships entering SA ports may have contributed to disseminate the yeast to places where it was normally not present. In addition, cities in the region typically discharge untreated wastewater directly into estuaries and oceans. The waters of the Bay of Málaga and surroundings (Colombia), Gulf of Guayaquil (Ecuador), Florianópolis, Laguna and Mampituba rivers (Brazil) and Lima (Peru) contain extremely high levels of fecal coliforms (SDM, 1998; CPPS, 2000; CVC, 2003; Haase et al., 2003²8) indicative of organic contamination and considered a major health threat to humans. In Brazil, all cases of lobomycosis and LLD, including the first report in an adult female bottlenose dolphin in 1990 in Laguna $\left(28^{\circ} 30^{\prime} \mathrm{S}, 48^{\circ} 55^{\prime} \mathrm{W}\right)$ by Simões-Lopes et al. (1993), were recorded between Baía Norte $\left(27^{\circ} 50^{\prime} \mathrm{S}, 48^{\circ} 58^{\prime} \mathrm{W}\right)$ and Tramandaí estuary (29 $58^{\prime} \mathrm{S}$, $\left.50^{\circ} 07^{\prime} \mathrm{W}\right)$. It is likely that LLD is endemic in the coastal population of T. truncatus from this area. The infection may represent a threat to possibly susceptible $S$. guianensis (de Vries and Laarman, 1973; Flores et al., 2005 ${ }^{18}$ ). Though the organism found in dolphins may not be the same as in humans (Haubold et al., 2000), lobomycosis and LLD may be zoonotic and care should be taken when manipulating affected dolphins (Symmers, 1983). Fishermen work closely to bottlenose dolphins during cooperative mullet fishing in Laguna, Torres and Tramandaí estuary (Simões-Lopes et al., 1998) and may be at risk of infection. Indications are that in Peru LLD is a newly emerging disease in inshore bottlenose dolphins. Further research on the aetiology and epizootiologic trends of skin diseases in small cetaceans from South America is urgently needed, including periodic surveys to assess the presence of cutaneous lesions and the analysis of existing image databases.

External injuries, body traumata and bone fractures caused by interaction with fisheries and boats were seen in inshore and offshore small cetaceans from both SW Atlantic and SE Pacific oceans. Severe traumata due to a variety of fishing devices likely result in secondary mortality of unassessed numbers of escaping but injured dolphins and porpoises. Therefore, total fisheries-related small cetacean mortality must be higher than can be accounted for by the tallying of landed specimens. A number of cases of incisive injuries, dorsal fin mutilation and bone fractures are the result of boat collisions, especially propeller hits, however other potential sources like fishing lines and post-mortem damage on carcasses must be excluded (Van Waerebeek et al., 2007). Boat collisions and net entanglements likely cause great stress in surviving animals. Chronic high levels of stress hormones may depress the immune system and favour the development of infectious diseases as well as damage the circulatory system and kidneys (e.g. Van Bressem et al., 1994; Cowan and Curry, 2002).

Various osteolytic lesions of the skull were common in several species of dolphins and in Burmeister's porpoises in Peru, Brazil and Venezuela. Periodontitis and dental diseases, impact or piercing traumata as well as Crassicauda spp. infestation were firmly or tentatively diagnosed as the origin for a high percentage of these conditions. In $P$. spinipinnis, periodontal and dental diseases were thought responsible for all the lytic injuries. These diseases are likely a consequence of tooth decay, infection and loss (De Smet, 1977). The loss of a large number of teeth with resulting damage to the alveoli and, eventually, lysis of surrounding bone tissue may lead to considerable pain in the affected animals. Post-traumatic osteolysis has been reported in humans (Ryan and Munk, 2004) and is thought to have been responsible for lysis found in the mandibles of a S. guianensis (Venezuela) and an offshore T. truncatus (Peru) examined during this study. Adult roundworms Crassicauda spp. infest the cranial sinuses and produce the typical, apparently irreversible, perforating lytic bone lesions with a basket-like appearance that often deform pterygoids (Raga et al., 1982; Dailey, 1985).

\footnotetext{
${ }^{28}$ Haase, J., Stringhini, M.H., Silva, M.L.B.C., Rodrigues, M.L.K. and Koch, S.M.V. (2003) Qualidade das águas superficiais do litoral norte e médio do Rio Grande do Sul. Pages 1-17 in 22 Congresso Brasileiro de Engenharia Sanitária e Ambiental, 14-19 September, 2003, Joinville, SC, Brazil.
} 
They were entirely absent in Peruvian P. spinipinnis. In the other species the highest prevalence was observed in the offshore/pelagic stocks, pointing to a prey relationship. Interestingly, in offshore T. truncatus and in $D$. capensis from Peru, mature and immature specimens were equally affected. However, the primary questions that need to be answered before differential age-related mortality can be confidently evaluated from skulls are whether the bone lesions remain extant long after the nematodes have died, and whether re-infection is likely. In pantropical spotted dolphins (Stenella attenuata) from the Eastern Tropical Pacific, prevalence was higher in younger animals, which was attributed to mortality caused by Crassicauda spp. infestation in young dolphins (Perrin and Powers, 1980). However, if most infested juveniles recovered, build some level of immunity and cranial lesions healed, it would also be consistent with findings. The osteomyelitic lesions observed in this study probably have a bacterial origin as in other mammals (Bubenik, 2005) though protozoans and fungi cannot be excluded. Brucellae are known to circulate among Peruvian D. capensis and may have caused orchitis and vertebral lesions in at least one specimen (Van Bressem et al., 2006b).

Degenerative diseases including hyperostosis and ankylosing spondylitis were especially prevalent in offshore T. truncatus from Peru, possibly related to deepwater feeding habits. There was some indication that hyperostosis may occur more frequently in adult males than in others but larger samples are required for testing. If confirmed, the hypothesis that the disease might be related to physiological (hyperbaric) stress associated with feeding at greater depths in adult males than in immatures and females would deserve further study. Hyperostosis seems to be linked to the development of ankylosing spondylitis. Prevalence of AS was similar in mature and immature male offshore T. truncatus. The only inshore dolphin with AS was a young immature. The aetiology of AS in humans is still poorly understood, but a strong genetic influence exists and approximately $90-95 \%$ of patients with AS have the tissue antigen human leukocyte antigen B27 (Dougados, 2005). Unknown environmental factors (bacterial infection in humans) may trigger the development of AS in individuals genetically predisposed. Hyperbaric stress related to deep diving may represent one of those factors in offshore T. truncatus and other species with similar feeding habits. Prevalence of AS was $21 \%$ in 52 longfinned pilot whales (Globicephala melas) from the Northwest Atlantic (Sweeny et al., 2005). Degenerative diseases called 'spondylitis' and 'spondylosis deformans' were previously described in small odontocetes (reviewed by Kompanje, 1995a,b).

The high prevalence of congenital bone malformations in S. guianensis from northern RJ is of great concern and likely indicates a genetic bottleneck in this population. The malformations possibly facilitated the occurrence of fractures seen in the vertebrae of this species (Fragoso,
2001; Laeta et al., 2006 ${ }^{20}$; this paper). At least $25 \%$ of the 167 photo-identified adult S. guianensis from Sepetiba Bay presented infectious skin diseases, body deformations, emaciation and traumata caused by boat collisions and non-lethal entanglement in gillnets. The injuries likely result in high stress levels and secondary mortality which goes unaccounted for. In addition, in both southern and northern RJ, coastal waters are heavily contaminated by industrial and domestic wastes (FEEMA, 2007). Altogether findings indicate that this $S$. guianensis population is in poor health and underscore the need to closely monitor health status including their genetic variability and to improve and enforce conservation measures.

We conclude that odontocetes from SA waters are affected by a variety of acquired, congenital, traumatic, infectious and parasitic diseases. Some of these are severe and bound to impair normal vital functions and behaviour. Interactions with artisanal and industrial fisheries and, to a lesser degree, boat collisions, are an important cause of debilitating physical traumata in several populations.The feasibility of applying fishing gear modifications and other potential bycatch mitigation measures, including regulatory instruments, should be re-evaluated in South America as one of the most relevant issues for the enhanced conservation of marine mammal populations. In addition, aquaculture, fish factories, untreated wastewater, ballast water as well as chemical pollution are believed to play a significant role in the detoriation of modal cetacean population health and in facilitating the emergence of new diseases. Further research to establish cause-effect relationships is required.

\section{Acknowledgements}

Field work in Peru from 1985 onwards and data analysis were supported by many organisations, the principal sponsors including the Belgian Agency for Developing Aid, Cetacean Society International, Gesellschaft zur Rettung der Delphine, Gesellschaft zum Schutz der Meeressäugetiere, IFAW, IUCN/ Cetacean Specialist Group, Leopold III Fonds voor Natuuronderzoek en Natuurbehoud, United Nations Environment Programme (UNEP) and Whale and Dolphin Conservation Society. The data on dolphins from northern Rio de Janeiro were collected during the 'Projeto Mamíferos e Quelônios Marinhos' developed and sponsored by 'Gerência de Avaliação e Monitoramento Ambiental do Centro de Pesquisas de PETROBRÁS'. Ana Paula Di Beneditto, Ignacio Moreno and Paulo Flores were supported by fellowships of the 'Conselho Nacional de Desenvolvimento Científico e Tecnológico - CNPq (Proc no. 300322/2003-8, Proc no. 140660/2004-6 and Proc no. 146609/1999-9, respectively). Fundación Yubarta was supported by the 'Corporación Ecofondo'. We kindly thank Silvana Gomes, who helped with carcass collection in northern 
RJ, Larissa Heinzelmann, Lilian Hoffmann and Sue Bridi Nakashima for helping with the collection of the stranded dolphin in Tramandaí River, as well as Mauro Borba (Faculdade de Veterinária/UFRGS) for the histological diagnostic of lobomycosis. We also thank Pablo Echegaray, director del Museo del Mar de Maldonado, Uruguay, Richard Möller for his help with specimens from Uruguay, Lilián Flórez-González, Patricia Falk-Fernández, Angela Recalde, Elizabeth Hernández, Juan Capella and Wilfredo Henao, Francisco Jávier Álvarez and Rafael Martan for their help in collecting data on LLD in Colombia, Augusto Carrillo for images of specimen JBJ SF 05-03, Francisco Bisbal and Javier Sánchez for providing access to samples under their custody in the EBRG Museum, Dr Víctor Bermúdez for his advice on diseases of Venezuelan small cetaceans and Martin Frixione for the photographs of C. commersonii. We gratefully acknowledge Dr J. A. Raga and an anonymous reviewer for their comments on the manuscript.

\section{References}

Aguilar, A. And Borrell, A. (1994) Abnormally high polychlorinated biphenyl levels in striped dolphins (Stenella coeruleoalba) affected by the 1990-1992 Mediterranean epizootic. Science of the Total Environment 154: 237-247.

Bolaños-Jimenez, J., CAMPO, M.A. AND GonZÁlez-Fernández. (1998) Estado actual de los cetáceos de las costas del Estado Aragua. Serie Informes Técnicos, Dirección General de Fauna/ IT/386, Ministerio del Ambiente y de los Recursos Naturales, Caracas, Venezuela.

Bracht, A.J., Brudek, R.L., Ewing, R.Y., MANire, C.A., BureK, K.A., Rosa, C., Beckmen, K.B., MaruniaK, J.E and Romero, C.H. (2006) Genetic identification of novel poxviruses of cetaceans and pinnipeds. Archives of Virology 151: 423-438.

Brownell, R. L. Jr., Carlson, C.A., Galletti Vernazzani, B. And Cabrera, E. (2007) Skin lesions on blue whales off Southern Chile: possible conservation implications? Paper SC/59/SH21 presented to the IWC Scientific Committee, May 2007 (unpublished).

BUBENIK, L.J. (2005) Infections of the skeletal system. Veterinary Clinics of North America: Small Animal Practice 35(5): 1093-1109.

Cabello, F.C. (2004) Antibioticos y acuicultura en Chile: consecuencias para la salud humana y animal. Revista de Medicina de Chile 132: 1001-1006.

Cabello, F.C. (2006) Heavy use of prophylactic antibiotics in aquaculture: a growing problem for human and animal health and for the environment. Environmental Microbiology 8:1137-1144.

Caldwell, D.K., Caldwell, M.C., Woodard, J.C., Ajello, L., Kaplan, W. and McLure, H.M. (1975) Lobomycosis as a disease of the Atlantic bottle-nosed dolphin (Tursiops truncatus Montagu, 1821). American Journal of Tropical Medicine 24: 105-114.

Comision Permanente Del Pacifico Sur - CPPS (1988) Estudio piloto para el ordenamiento ambiental del área Pisco Paracas (Ica, Peru), Volumen I: Diagnóstico Ambiental del área de Pisco Paracas. Lima, Peru. 331 pp.
Comision Permanente Del Pacifico Sur - CPPS (2000) Estado del Medio Ambiente Marino y Costero del Pacífico Sudeste. Quito, Ecuador. 165 pp.

Copeland, G., Monteiro, T., Couch, S. And Borthwick, A. (2003) Water quality in Sepetiba Bay, Brazil. Marine Environment Research 5: 385-408.

Corporacion Autonoma Regional Del Valle Del Cauca-CVC. (2003) Plan de gestión ambiental regional del Valle del Cauca 2002 -2012: Participación con Compromiso. Grupo de Planificación Ambiental y Grupo Archivo Corporativo. Segunda Edición. Cali, Colombia. 264 pp.

Clark, L.S., Cowan, D.F. and Pfeiffer, D.C. (2006) Morphological changes in the Atlantic bottlenose dolphin (Tursiops truncatus) adrenal gland associated with chronic stress. Journal of Comparative Pathology 135: 208-16.

Cowan, D. And Curry, B. (2002) Histopathological assessment of dolphins necropsied onboard vessels in the eastern tropical pacific tuna fishery, Southwest Fisheries Science Center, National Marine Fisheries Service, NOAA Administrative Report LJ-02-24C. 31 pp.

CusICK, P.K. AND BULLOCK, B.C. (1973) Ulcerative dermatitis and pneumonia associated with Aeromonas hydrophila infection in the bottle-nosed dolphin. Journal of the American Veterinary Medicine Association 163: 578-579.

DAILEY, M.D. (1985) Diseases of Mammalia: Cetacea. Pages 805847 in: Kinne, O. (Ed) Diseases of Marine Mammals. Vol 4 (2). Biologische Anstalt Helgoland, Hamburg, Germany.

DE SMET, W.M.A. (1977) The fate of old bottle-nosed dolphins, Tursiops truncatus, in nature as revealed by the condition of their skeletons. Aquatic Mammals 5(3): 78-86.

De VRies, G.A. and LaArman, J.J. (1973) A case of Lobo's disease in the dolphin Sotalia guianensis. Aquatic Mammals 1: 26-33.

Dougados, M. (2005) Ankylosing spondylitis. Orphanet Encyclopedia. www.orfa.net/data/patho/GB/uk-as.pdf.

Drake, L., Doblin, M.A, DobBs, F.C. (2007) Potential microbial bioinvasions via ships' ballast water, sediment, and biofilm. Marine Pollution Bulletin 55: 333-341

FEEMA - Fundação Estadual de Engenharia e Meio Ambiente (2007) Rio Paraíba do Sul. Available at: http:// www.feema.rj.gov.br/bacia-rio-paraiba-sul.asp?cat $=75$ Accessed on 26 Mar. 2007.

Félix, F. (1997) Organization and social structure of the bottlenose dolphin Tursiops truncatus in the Gulf of Guayaquil, Ecuador. Aquatic Mammals 23: 1-16.

Flom, J.O. AND Houk, E.J. (1979) Morphologic evidence of poxvirus in 'tattoo' lesions from captive bottlenosed dolphins. Journal of Wildlife Diseases 15: 593-596.

Flores, P.A.C. \& Fontoura, N.F. (2006) Ecology of marine tucuxi, Sotalia guianensis, and bottlenose dolphin, Tursiops truncatus, in Baía Norte, Santa Catarina state, southern Brazil. Latin American Journal of Aquatic Mammals 5: 105-115.

Fragoso, A.B.L. (2001) Alterações morfólogicas e patológicas em esqueletos de boto-cinza Sotalia fluviatilis (Gervais, 1853) do litoral do estado do Rio de Janeiro. MSc Thesis, Universidade Federal do Rio de Janeiro, Museu Nacional, Rio de Janeiro, RJ, Brazil. 136 pp. 
Geraci, J.R., Hicks, B.D. And St Aubin, D.J. (1979) Dolphin pox: a skin disease of cetaceans. Canadian Journal of Comparative Medicine 43: 399-404.

Geraci, J.R. AND Lounsbury, V.J. (Eds). (1993). Marine Mammals Ashore, a Field Guide for Strandings. Texas A\&M University Sea Grant College Program, Galveston, TX, USA.

Haubold, E.M., CoOper, C.R. JR, Wen, J.W., McGinNIS, M.R. AND CowAN, D.F. (2000) Comparative morphology of Lacazia loboi (syn. Loboa loboi) in dolphins and humans. Medical Mycology 38: 9-14.

HERZING, D.L. (1997) The natural history of free-ranging Atlantic spotted dolphins (Stenella frontalis): age classes, color phases, and female reproduction. Marine Mammal Science 13 (4): 575-595.

HofFmanN, L.S. (2004) Um estudo de longa duração de um grupo costeiro de golfinhos Tursiops truncatus (Montagu, 1821) (Cetacea, Delphinidae) no sul do Brasil: aspectos de sua biologia e bioacústica. Ph.D. Thesis. Universidade Federal do Rio Grande do Sul, Porto Alegre, Brazil. 273 pp.

Honda, K., Horner, K. and Raugi, G.J. (2007) Lobomycosis. in Fivenson, D.P., Butler, D.F., CAllen, J.P, Quirk, C. And Elston, D.M. (Eds) e-Medicine World Medical Library online: http:/ / www.emedicine.com/derm/topic832.htm.

JePSON, P. AND BAKER, J.R. (1998) Bottlenosed dolphins (Tursiops truncatus) as a possible cause of acute traumatic injuries in porpoises (Phocoena phocoena). Veterinary Record 28: 614-615.

Jepson, P.D., Bennett, P.M., Allchin, C.R., LaW, R.J., Kuiken, T., BaKer, J.R., Rogan, E. AND Kirkwood, J.K. (1999) Investigating potential associations between chronic exposure to polychlorinated biphenyls and infectious disease mortality in harbor porpoises from England and Wales. Science of the Total Environment 243/244: 339-348.

Kemper, C.M., Pemberton, D., Cawthorn, M., Heinrich, S., Mann, J., Würsig, B., Shaughnessy, P. And Gales, R. (2003) Aquaculture and marine mammals: Co-existence or Conflict? Pages 209-225. in Gales, N., Hindell, M. AND KIRKWOOD, R. (Eds) Marine Mammals: Fisheries, Tourism and Management Issues. CSIRO, Melbourne, Australia.

Kompanje, E.J.O. (1995a). Differences between spondyloosteomyelitis and spondylosis deformans in small odontocetes based on museum material. Aquatic Mammals 21: 199-203.

Kompanje, E.J.O. (1995b). On the occurrence of spondylosis deformans in white-beaked dolphins Lagenorhynchus albirostris (Gray, 1846) stranded on the Dutch coast. Zoologische Mededelingen, Leiden 69: 231-250.

Migaki, G., Valerio, M.G., Irvine, B.A and Graner, F.M. (1971) Lobo's disease in an Atlantic bottle-nosed dolphin. Journal of the American Veterinary Medicine Association 159: 578-582.

Molisani, M.M., Marins, R.V., Machado, W., Paraquetti, H.H.M., BIDONE, E.D. AND LACERDA, L.D. (2004) Environmental changes in Sepetiba Bay, SE Brazil. Regional Environmental Change 4: 17-27.

Montes-Iturrizaga, D. (2003) Descripción y evaluación de alteraciones anatómicas óseas cráneo-mandibulares en cetáceos odontocetos del mar peruano. BSc Thesis, National University of San Marcos, Lima, Peru. 86 pp.

Montes, D.I., Chavera, A.C., Van Bresem, M.-F., Perales, R.C., Falcón, N.P. and Van Waerebeek, K. (2004) Descripción y evaluación anatómica de lesiones óseas cráneo-mandibulares en cetáceos odontocetos del mar peruano. Revista de Investigaciones Veterinarias del Perú 15: 13-24.

Moore, K And Wieting, D. (1999) Marine aquaculture, marine mammals, and marine turtles interaction workshop. 12-13 January 1999, Silver Spring, MD. U.S. Department of Commerce, NOAA Technical Memorandum NMFS-OPR-16, 60 pp.

Norman, S.A., Raverty, S., McLellan, B., Pabst, A., Ketten, D., Fleetwood, M., Gaydos, J.K., Norberg, B., Barre, L., Cox, T., HANSON, B., AND JEFFRIES, S. (2004) Multidisciplinary investigation of stranded harbor porpoises (Phocoena phocoena) in Washington State with an assessment of acoustic trauma as a contributory factor (2 May - 2 June 2003). U.S. Department of Commerce, NOAA Technical Memorandum NMFS-NWR-34, 120 pp.

OTт, P.H. 2004. Tem boto na pescaria. E não é na rede de pesca!. Ciência Hoje das Crianças 2-6

Perrin, W.F. AND Powers, J.E. (1980) Role of a nematode in natural mortality of spotted dolphins. Journal of Wildlife Management 44: 960-963.

PNUMA/CONAM (2006) Informe sobre el Estado del Medio Ambiente. GEO Bahía Paracas-Pisco. Lima, Peru. 164 pp.

Raga, J.A., Casinos, A., Filella, S. and Raduan M.A. (1982) Notes on cetaceans of the Iberian coasts. V. Crassicauda grampicola Johnston and Mawson, 1941 (Nematoda) cause of injuries in the pterygoids of some specimens of Grampus griseus. Säugetierkundliche Mitteilungen 30: 315-318.

Ramos, R.M.A., Di Beneditto, A.P.M. And Mendonça de SouzA, S. (2001) Bone lesions in Sotalia fluviatilis (Cetacea) as a consequence of entanglement. Case report. Brazilian Journal of Veterinary Research and Animal Science 38: 192-195.

Reif, J.S., Mazzoil, M.S., McCullogh, S.D., Varela, R., Goldstein, J.D., Fair, P. And Bossart, G.D. (2006) Lobomycosis in Atlantic bottlenose dolphins from the Indian River Lagoon, Florida. Journal of the American Veterinary Medicine Association 228: $104-108$

ReYes, J.C. And VAn WAEREBEeK, K. (1995) Aspects of the biology of Burmeister's porpoise from Peru. Report of the International Whaling Commission (special issue 16): 349-364.

Ross, P.S.R. (2002) The role of immunotoxic environmental contaminants in facilitating the emergence of infectious diseases in marine mammals. Human and Ecological Risk Assessment 8: 277-292.

Ruiz, G.M., Rawlings, T.K., Dobbs, F.C., DraKe, L.A., Mullady, T., HuQ, A., And Colwell, R.R. (2000) Global spread of microorganisms by ships. Nature 408: 49-50.

RYAN, R.S. AND MunK, P.L. (2004) Radiology for the surgeon: musculoskeletal case 33. Canadian Journal of Surgery 47: 372-373.

SÁnchez, J., KubA, L., Berón-Vera, B., Dans, S.L., Crespo, E.A., Van Bressem, M.-F., Coscarella, M.A., García, N.A., Alonso, M.K., Pedraza, S.N. and Mariotti, P.A. (2002) Uterine adenocarcinoma with generalised metastasis in a bottlenose dolphin Tursiops truncatus from northern Patagonia, Argentina. Diseases of Aquatic Organisms 48: 155-159.

SAnino, G.P. And YÁÑEZ, J. (2001) Nueva técnica de video identificación y estimación de tamaño poblacional en cetáceos, aplicada en delfines nariz de botella, Tursiops truncatus, de Isla Choros, IV región de Chile. Boletín del Museo Nacional de Historia Natural, Santiago 50: 37-63. 
Sanino, G.P., Hamilton-West, C., Rojas, A., Yañez, J.L. and Van WAEREBEEK, K. (2003) Estudios de restos varados de Delphinus delphis, y primer registro documentado de Pneumonia focal abscedativa, en Chile. Boletín del Museo Nacional de Historia Natural, Santiago 52: 103-117.

SDM (1998) Diagnóstico dos recursos hídricos e organização dos agentes da Bacia Hidrográfica do Rio Tubarão e Complexo Lagunar. Secretaria de Estado do Desenvolvimento Urbano e Meio Ambiente. Florianópolis, SC, Brazil. 163pp. http:// www.comitetubarao.unisul.br/gruperh/meio-ambiente.html.

SHANe, S.H. (1990) Behavior and ecology of the bottlenose dolphin at Sanibel Island, Florida. Pages 245-265 in Leatherwood, S. And ReEves, R.R. (Eds) The Bottlenose Dolphin. Academic Press, San Diego, CA, USA.

Siciliano, S., Hassel, L.B., da Costa Cuenca, S., Mendonça de SouZA, S., DitTMAR, K. (in press). A case of osteochondromatosis in an orca (Orcinus orca: Cetacea, Delphinidae) of the coast of Rio de Janeiro, Brazil. Journal of Comparative Pathology.

Simões-Lopes, P.C., Paula, G.S. and Xavier, F.M., Scaramelo, A.C. (1993) First case of lobomycosis in bottlenose dolphin from Southern Brazil. Marine Mammal Science 9: 329 - 331.

Simões-Lopes, P.C., Fabián, M.E. and Menegheti, J.O. (1998) Dolphin interactions with the mullet artisanal fishing from Southern Brazil: a qualitative and quantitative approach. Revista Brasileira de Zoologia 15: 709-726.

Smith, A.W., Skilling, D.E. and Ridgway, S.H. (1983). Calicivirus-induced vesicular disease in cetaceans and probable interspecies transmission. Journal of the American Veterinary Medicine Association 11: 1223-1225.

Smyth, M., Berrow, S., Nixon, E. and Rogan, E. (2000) Polychlorinated biphenyls and organochlorines in by-caught harbour porpoises Phocoena phocoena and common dolphins Delphinus delphis from Irish coastal waters. Biology and Environment. Proceedings of the Royal Irish Academy 100B: 85-96.

SweEnY, M.M., Price, J.M., Jones, G.S., French, T.W., EArly, G.A. AND MOORE, M. (2005) Spondylitic changes in long-finned pilot whales (Globicephala melas) stranded on Cape Cod, Massachusetts, USA, between 1982 and 2000. Journal of Wildlife Diseases 41: 717-727.

Swinscow, T.D.V. (1981) Statistics at Square One, 7th ed. British Medical Association, London, United Kingdom.

SYMMERS, W.S. (1983) A possible case of Lobo's disease acquired in Europe from a bottle-nosed dolphin (Tursiops truncatus). Bulletin de la Société de Pathologie Exotique et de ses Filiales 76: 777-784.

TABordA, P.R., TABordA, V.A. AND McGinnins, M.R. (1999) Lacazia loboi gen. Nov., comb., the etiologic agent of Lobomycosis. Journal of Clinical Microbiology 37: 2031-2033.

Thrusfield, M. (Ed). (1986). Veterinary Epidemiology. Butterworths \& Co, London, United Kingdom. 280 pp.

UNEP. (2006) Permanent Commission for the South Pacific (CPPS). Humboldt Current, GIWA Regional Assessment 64. University of Kalmar, Kalmar, Sweden. 98 pp.

Van Bressem, M.-F. ANd Van Waerebeek, K. (1996) Epidemiology of poxvirus in small cetaceans from the Eastern South Pacific. Marine Mammal Science 12: 371-382.

Van Bressem, M.-F., Van Waerebeek, K., Reyes, J-C., Dekegel, D. AND PASTORET, P-P. (1993) Evidence of poxvirus in dusky dolphin (Lagenorhynchus obscurus) and Burmeister's porpoise (Phocoena spinipinnis) from coastal Peru. Journal of Wildife Diseases 29: 109-113.

Van Bressem, M.-F., Van Waerebeek, K., Garcia-Godos, A., Dekegel, D. ANd Pastoret, P.-P. (1994) Herpes-like virus in dusky dolphins, Lagenorhynchus obscurus, from coastal Peru. Marine Mammal Science 10: 354-359.

Van Bressem, M.-F., Van Waerebeek, K., Piérard, G. and DesAinTES, C. (1996) Genital and lingual warts in small cetaceans from coastal Peru. Diseases of Aquatic Organisms 26: 1-10.

Van Bressem, M.-F., Van Waerebeek, K., Flemming, M. and BARRETT, T. (1998) Serological evidence of morbillivirus infection in small cetaceans from the Southeast Pacific. Veterinary Microbiology 2: 89-98.

Van Bressem, M.-F., Van Waerebeek, K. and Raga, J.A. (1999) A review of virus infections of cetaceans and the potential impact of morbilliviruses, poxviruses and papillomaviruses on host population dynamics. Diseases of Aquatic Organisms 38: 53-65.

Van Bressem, M.-F., Van Waerebeek, K., Siebert, U., Wünschmann, A., Chávez-Lisambart, L. and Reyes, J.C. (2000) Genital diseases in the Peruvian dusky dolphin (Lagenorhynchus obscurus). Journal of Comparative Pathology 122: 266-277.

Van Bressem, M.-F., Van Waerebeek, K., Raga, J.A., Godfroid, J., Brew, S.D. ANd MacMillan, A.P. (2001a). Serological evidence of Brucella species infection in odontocetes from the South Pacific and the Mediterranean. Veterinary Record 148: 657-661.

Van Bressem, M.-F., Van Waerebeek, K., Jepson, P.D., Raga, J.A., Duignan, P.J., Nielsen, O., Di Beneditto, A.P., Siciliano, S., Ramos, R., Kant, W., Peddemors, V., Kinoshita, R., Ross, P.S., Lopez-Fernandez, A., Evans, K., Crespo, E. and Barrett, T. $(2001 b)$. An insight into the epidemiology of dolphin morbillivirus worldwide. Veterinary Microbiology 81: 287-304.

Van Bressem, M.-F., Van Waerebeek, K., Raga, J.A., Gaspar, R., Di BeneditTo, A.P., Ramos, R. And Siebert, U. (2003a) Tattoo disease of odontocetes as a potential indicator of a degrading or stressful environment: a preliminary report. Document SC/ 55/E1, International Whaling Commission, Berlin, Germany.

Van Bressem, M.-F., Gaspar, R. and J. Aznar. (2003b) Epidemiology of tattoo skin disease in bottlenose dolphins (Tursiops truncatus) from the Sado estuary, Portugal. Diseases of Aquatic Organisms 56: 171-179.

VAn Bressem, M.-F., VAn WAerebeeK, K. And BennetT, M. (2006a) Orthopoxvirus neutralising antibodies in small cetaceans from the Southeast Pacific. The Latin American Journal of Aquatic Mammals 5(1): 49-54.

Van Bressem, M.-F., Van Waerebeek, K., Montes, D., Kennedy, S., Reyes J.C., Garcia-Godos, A.I., Onton-Silva, K. and AlfaroShigueto, J. (2006b) Diseases, lesions and malformations in the long-beaked common dolphin (Delphinus capensis) from the Southeast Pacific. Diseases of Aquatic Organisms 68: 149-165.

Van Bressem, M.-F., Cassonnet, P., Rector, A., Desaintes, C., Van Waerebeek, K., Alfaro-Shigueto, J., Van Ranst, M and ORTH, G. (2007a) Genital warts in Burmeister's porpoises: characterization of Phocoena spinipinnis papillomavirus type 1 (PsPV-1) and evidence for a second, distantly related PSPV. Journal of General Virology 88: 1928-1933. 
Van Bressem, M.-F., Raga, A.J., Barrett, T., Siciliano, S., Di Beneditto, A.P., Crespo, E. And Van Waerebeek, K. (2007b) A brief review of micro-parasites that may have a potential impact on the population dynamics of small cetaceans from South America. Paper SC/59/DW8 presented to the IWC Scientific Committee, May 2007 (unpublished).

Van Waerebeek, K. (1992) Population identity and general biology of the dusky dolphin Lagenorhynchus obscurus (Gray, 1828) in the Southeast Pacific. PhD Thesis, University of Amsterdam, The Netherlands. $76 \mathrm{pp}$.

VAN WAEREBEeK, K. (1993) Geographic variation and sexual dimorphism in the skull of the dusky dolphin, Lagenorhynchus obscurus (Gray, 1828). Fishery Bulletin 91: 754-774.

Van Waerebeek, K., Reyes, J.C., Read, A.J. And McKinnon, J.S. (1990) Preliminary observations of bottlenose dolphins from the Pacific coast of South America. Pages 143-154. in Leatherwood, S. and Reeves, R.R. (Eds). The Bottlenose Dolphin. Academic Press, San Diego, CA, USA.

Van WaerebeeK, K., Baker, A.N, Félix, F., Gedamke, J., IÑigueZ,
M., Sanino, G.P., Secchi, E., Sutaria, D., van Helden, A. And WANG, Y. (2007) Vessel collisions with small cetaceans worldwide and with large whales in the Southern Hemisphere, an initial assessment. Latin American Journal of Aquatic Mammals 6(1): 43-69 (this volume).

Vilani-Moreno, F.R., Lauris, J.R. and Opromolla, D.V. (2005) Cytokine quantification in the supernatant of mononuclear cell cultures and in blood serum from patients with Jorge Lobo's disease. Mycopathology 158: 17-24.

Wells, R.S., Irvine, A. B. And Scott, M.D. (1980) The social ecology of inshore odontocetes. Pages 263-317 in Herman, L.M. (Ed). Cetacean Behavior: Mechanisms and Functions. John Wiley and Sons, New York, NY, USA.

WHO/UNICEF/WSSCC. (2001) Global Water Supply and Sanitation Assessment 2001. Report World Health Organization and United Nations Children's Found.

WÜrsig, B. AND JeFFERson, R.A. (1990) Methods of photoidentification for small cetaceans. Report of the International Whaling Commission (special issue 12): 42-43. 